Revista Española de Derecho Internacional Sección JURISPRUDENCIA DIPub Vol. 67/1, enero-junio 2015, Madrid, pp. 179-229 http://dx.doi.org/10.17103/redi.67.1.2015.3a

(C) 2015 Asociación de Profesores de Derecho Internacional y Relaciones Internacionales ISSN: 0034-9380; E-ISSN: 2387-1253

\section{JURISPRUDENCIA}

\title{
A) JURISPRUDENCIA ESPAÑOLA EN MATERIA DE DERECHO INTERNACIONAL PÚBLICO *
}

\author{
Coordinación a cargo de \\ Gabriela A. OANTA \\ Profesora contratada doctora \\ Universidade da Coruña
}

SUMARIO: 1. INTRODUCCIÓN.-2. PRESENTACIÓN GENERAL.-3. COMENTARIOS DE SENTENCIAS.-3.1. El Sáhara Occidental: posibilidad de continuar instruyendo un proceso relativo a supuestas violaciones graves de derechos humanos.-3.2. Jurisdicción universal: casos Tíbet y Falun Gong.-3.3. Competencia extraterritorial de los tribunales penales españoles.-3.4. Jurisdicción universal: delitos contra la salud pública.-3.5. La denegación del derecho de asilo y de la protección subsidiaria por motivos de seguridad nacional.-3.6. El valor de la documentación frente a la realidad física para determinar la edad de un menor extranjero no acompañado.-3.7. «Devoluciones en caliente» de ciudadanos extranjeros a Marruecos.-3.8. Ejecución de sentencias del Tribunal Europeo de Derechos Humanos.-3.9. El contrato de trabajo por tiempo indefinido de apoyo a los emprendedores ante el Derecho internacional.

\section{INTRODUCCIÓN}

1. La presente crónica comprende la jurisprudencia recaída desde julio hasta diciembre de 2014, y sigue los criterios aplicados en crónicas precedentes, es decir, destacando las referencias a los pronunciamientos de los órganos jurisdiccionales y

* Desde el núm. 2 de 2014, esta crónica de jurisprudencia está a cargo de un equipo compuesto por cuatro coordinadores: Belén Sánchez Ramos (Profesora Contratada Doctora de la Universidade de Vigo), Jorge Antonio Quindimil (Profesor Contratado Doctor de la Universidade da Coruña), Gabriela A. Oanta (Profesora Contratada Doctora de la Universidade da Coruña) y Paula García Andrade (Doctora, Profesora Colaboradora Asistente, Universidad Pontificia Comillas, Madrid), bajo la dirección de José Manuel Sobrino Heredia (Catedrático de la Universidade da Coruña). Cada crónica se elabora bajo la responsabilidad de uno de los coordinadores. 
del Tribunal Constitucional (TC) que contienen elementos relevantes de Derecho internacional público (DIP). En concreto, en esta crónica se consideran las decisiones tanto del TC, como del Tribunal Supremo (TS), la Audiencia Nacional (AN) y los Tribunales Superiores de Justicia (TSJ).

2. La crónica, que está estructurada conforme al índice que precede a esta Introducción, presenta, en primer lugar, un panorama general de los pronunciamientos de los distintos órganos judiciales en los que se ha prestado atención a la aplicación del Ordenamiento jurídico internacional como parte del Ordenamiento jurídico español, pero sin que ello representase un cambio importante en la doctrina de dichos órganos. Y, en segundo lugar, se han incorporado una serie de comentarios más amplios de aquellos pronunciamientos judiciales que han sido objeto de un tratamiento particularizado al resultar éstos especialmente interesantes desde la perspectiva del DIP. Como es habitual, el mayor número de pronunciamientos están relacionados con la aplicación e interpretación de distintos instrumentos internacionales en materia de derechos humanos con múltiples referencias al Convenio Europeo de Derechos Humanos (CEDH) y a la jurisprudencia del Tribunal Europeo de Derechos Humanos (TEDH). No obstante, cabe señalar que en esta crónica nos referimos, también, a aquellas resoluciones que abordan otros temas de interés, como: la jurisdicción universal sobre crímenes internacionales, el derecho de asilo, la apatridia, cuestiones de extranjería, el interés superior del menor, Derecho del mar, obligaciones convencionales contraídas por España, y terrorismo, entre otros.

\section{PRESENTACIÓN GENERAL}

1. Durante este semestre, la aplicación del principio de jurisdicción universal como consecuencia de la entrada en vigor, el 15 de marzo de 2014, de la LO 1/2014, de 13 de marzo, de modificación de la LOPJ relativa a la justicia universal, ha seguido ocupando un lugar importante en la labor judicial de nuestros Tribunales, que se han tenido que pronunciar sobre el mantenimiento o no del ejercicio de la jurisdicción por los mismos. En relación con ello, cabe destacar cuatro autos pronunciados en el mes de julio de 2014 por la Sala de lo Penal de la AN. Así, y, en primer lugar, hay que mencionar el AAN de 4 de julio de 2014 (ROJ: AAN 256/2014) relativo a la comisión de los delitos de lesa humanidad y genocidio en el desalojo del asentamiento Gdeim Izik (conocido como Campamento de la Dignidad) en las proximidades de la ciudad del Aaiún en el territorio del Sáhara Occidental. En este auto, que es objeto de un comentario más extenso en el apartado 3.1 de esta sección, la Sala de lo Penal de la AN ha concluido que la jurisdicción española es competente en este asunto en aplicación del criterio de territorialidad (art. 23.1 de la LOPJ), resultando, por tanto, inaplicable la disposición transitoria única de la LO 1/2014. En segundo lugar, cabe referirse a dos autos publicados por el Pleno de la Sala de lo Penal de la AN en el asunto del Genocidio en el Tíbet (ROJ: AAN 216/2014, de 2 de julio) y en el caso de la querella abierta al grupo Falun Gong (ROJ: AAN 215/2014, de 15 de julio); en ambos casos, se acuerda el sobreseimiento al considerar la Sala que no concurren los requisitos que establece el art. 23 de la LO 1/2014, de 13 de marzo, si bien ambos pronunciamientos van acompañados de votos particulares. Estos asuntos son objeto de estudio particularizado en el apartado 3.2 de esta crónica. Y, en tercer lugar, en relación con el tráfico de estupefacientes, el Pleno de la Sala de lo Penal de la AN se ha pronunciado en un Auto de 4 de julio (ROJ: AAN 255/2014) sobre el sobreseimiento de la causa al entender que no concurren los requisitos que establece el art. 23 de la LO 1/2014, de 13 de marzo. Este 
asunto, que va acompañado de un voto particular, será objeto de análisis amplio en el apartado 3.3 de esta sección.

2. Además de la AN, también el TS fue resolviendo varios de los casos que le fueron llegando como consecuencia de la entrada en vigor, el pasado 15 de marzo de 2014, de la LO 1/2014. Al igual que sucediera en el primer semestre de 2014 con la AN, esta importante modificación legislativa ha dado lugar a una serie de resoluciones judiciales del TS sobre el mantenimiento o no del ejercicio de la jurisdicción por nuestros Tribunales, en relación con casos vinculados con el tráfico de estupefacientes en aguas internacionales (ROJ: STS 3082/2014 y ROJ: STS 3089/2014, ambas de 24 de julio, y ROJ: ATS 7517/2014, de 18 de septiembre -las tres resoluciones son objeto de un comentario más extenso en el apdo. 3.4 de esta crónica-; ROJ: ATS 7890/2014, de 13 de octubre; ROJ: STS 4731/2014, de 5 de noviembre; ROJ: STS 4923/2014, de 3 de diciembre; y ROJ: STS 1259/2014, de 5 de diciembre).

3. Por lo que se refiere a asuntos relacionados con el Sáhara Occidental, a diferencia del semestre analizado en la crónica anterior donde se produjo una gran actividad jurisprudencial, en esta ocasión apenas se han resuelto dos casos que se corresponden con sendas solicitudes de protección internacional, siendo una de las sentencias estimatoria (ROJ: STS 3182/2014, de 23 de julio), sobre la base de una línea jurisprudencial consolidada, y la otra desestimatoria (ROJ: STS 3370/2014, de 23 de julio).

4. Gran parte de la actividad jurisdiccional de la AN desarrollada durante el semestre objeto de atención en la presente crónica ha sido realizada en el marco de las solicitudes de asilo. En este sentido, destaca una sentencia de la Sala de lo Contencioso (ROJ: SAN 3633/2014, de 17 de julio) en la que la AN se ha pronunciado en el asunto Pavlov anulando la resolución por la que el Ministerio del Interior había denegado el asilo a Alexander Pavlov, al estimar parcialmente el recurso del ciudadano kazajo por entender que el acto del Ministerio no se había amparado en razones fundadas que constatasen que constituyera un peligro para la seguridad en España. Esta resolución, que es objeto de un comentario más amplio en el apartado 3.5 de esta sección, cuenta con un voto particular en el que, si bien coinciden que no se ha motivado suficientemente que Pavlov sea un peligro para la seguridad en España, entienden, además, que se tendría que haber pronunciado sobre el fondo del asunto concediendo el asilo al recurrente.

5. Además de esta sentencia, cabe referirse, también, a una serie de sentencias de la AN que, si bien no modifican o cambian la línea jurisprudencial en el ámbito del asilo, sí merecen reseñarse en la medida en la que aplican diferentes normas de DIP. Así, en algunas sentencias la AN ha desestimado recursos y ha confirmado la denegación del derecho de asilo y de la protección subsidiaria (ROJ: SAN 4939/2014, de 23 de diciembre; SAN 4572/2014, de 27 de noviembre, 3928/2014). Aun así, también cabe apuntar algún asunto en el que la Sala de lo Contencioso-Administrativo ha declarado improcedente la denegación de asilo y la protección subsidiaria. A título de ejemplo, cabe mencionar la Sentencia de 16 de octubre (ROJ: SAN 3984/2014) en la que la AN conoce de un recurso en el que el demandante — natural de Costa de Marfil— alegaba haber sido reclutado por los rebeldes como niño de la guerra, trasladándose a Vavoua (desde Man, su localidad natal) cuando contaba con sólo catorce años. Edad en la que empezó a ser adiestrado en el uso de las armas por los «jefes de guerra», quienes le obligaban a drogarse diariamente. En su pronunciamiento, la AN recuerda - frente a la resolución recurrida, que denegaba el asilo solicitado al entender que el relato ofrecido era incongruente y genérico por el tiempo transcurrido entre su llegada a España y su petición de protección y por haber tenido la oportunidad de interesar 
el asilo en otro Estado antes de su llegada a España- que conforme al art. 23.4 CE, la Ley 12/2009, de 30 de octubre, Reguladora del Derecho de Asilo y la Protección Subsidiaria, la Convención sobre el Estatuto de los Refugiados de 1951, el Protocolo de Nueva York de 1967, así como reiterada jurisprudencia del TS que «en materia de asilo es aceptable una prueba semiplena o indiciaria cuando en ella se respetan esas exigencias y cuando de su evaluación crítica por parte de los Tribunales cabe extraer como conclusión no ya la presencia de un temor fundado a padecer persecución en su país de origen y que dicha persecución racionalmente temida obedezca a motivos, como hemos visto, de "raza, religión, nacionalidad, opinión política o pertenencia a un grupo social determinado...", y provenga, tal como se exige en los artículos 13 y 14 de la Ley de Asilo, por acción o por omisión probada, de agentes gubernamentales, en un sentido amplio de la expresión, sin que como esta Sala ha declarado reiteradamente, el derecho de asilo sea un instrumento jurídico idóneo para conjurar la amenaza para la vida, integridad física o libertad del peticionario cuando procede de grupos terroristas ajenos al Estado, de delincuentes comunes, del crimen organizado o de los grupos rebeldes a los que se refiere el aquí demandante (cuya existencia y actividades es admitida por la propia Administración), a menos que, como tan repetidamente se ha dicho, no haya podido obtenerse la tutela o protección de éste, porque no haya podido o no haya querido dispensarla» (FJ 3). La AN concluyó acertadamente, a nuestro entender, que «si el relato es coherente, verosímil y creíble, si se aduce una condición en el solicitante [...] que es digna de protección internacional y si, en fin, del material probatorio de que se dispone cabe colegir, indiciariamente al menos, la realidad de la persecución padecida, hubiera sido necesario una mínima actividad administrativa [...] Ni la resolución administrativa (absolutamente lacónica en sus fundamentos) ni los informes que les sirven de antecedente constatan ese mínimo esfuerzo para rebatir tal relato fáctico» (FJ 3). En la misma línea, la Sala de lo Contencioso-Administrativo de la AN, en su Sentencia de 24 de noviembre (ROJ: SAN 4675/2014), ha estimado en parte un recurso por el que la demandante — esta vez, nacional de Guinea Conakrysolicitaba asilo en España, alegando la concurrencia de las condiciones para la obtención de dicho estatuto por haber sido sometida a mutilación genital y posteriormente obligada por sus propios padres a casarse con un hombre mucho mayor que ella, que la maltrató y abusó sexualmente de ella — al considerar el Tribunal que «los informes obrantes en el expediente sobre la situación psicológica de la recurrente, en relación con la situación vivida en su país, el desarraigo en el que se encuentra respecto de dicho país, del que salió en el año 2007 por no aceptar las condiciones de vida que le vinieron impuestas en aras a unas costumbres y tradiciones que no comparte y se niega a aceptar, tal como se expone en el informe de ACNUR, permiten considerar que, efectivamente, la recurrente se encuentra en una situación vulnerable que, sin duda, se vería agravada en caso de tener que regresar al país en el que sufrió una experiencia traumática. Lo que permite considerar justificada la autorización de su permanencia en España por razones humanitarias»- (FJ 5). Continuando con la actividad jurisprudencial de los órganos españoles, cabe resaltar que, como también es habitual en relación con los campos del asilo y el refugio, el TS ha tenido que resolver un gran número de casos de solicitudes procedentes de nacionales de países como: Cuba (ROJ: STS 3974/2014, de 10 de octubre), Colombia (ROJ: STS 3243/2014, de 24 de julio), Argentina (ROJ: STS 3880/2014, de 6 de octubre), Costa de Marfil (ROJ: STS 4032/2014, de 10 de octubre) o Guinea Conakry (ROJ: STS 3379/2014, de 25 de julio), entre muchos otros casos.

6. En materia de extradición, ha de destacarse una sentencia del TS de 17 de noviembre de 2014 (ROJ: STS 4684/2014) cuya relevancia para el DIP deriva del hecho 
de que este Tribunal constata el incumplimiento del Gobierno español de su obligación de adoptar todas las medidas pertinentes para conseguir la devolución de un ciudadano español extraditado a Estados Unidos bajo la condición de ser devuelto a España para el cumplimiento de condena. Por lo que se refiere a los derechos de los españoles en el extranjero y la aplicación del principio de igualdad, cabe resaltar la STC 153/2014, de 25 de septiembre, sobre un recurso de inconstitucionalidad interpuesto por el Gobierno de Canarias en relación con varios apartados del artículo único de la LO 2/2011, de 28 de enero, por la que se modifica la LO 5/1985, de 19 de junio, del régimen electoral general (LOREG). La parte demandante consideraba que estas disposiciones suponen la restricción del derecho de voto en las elecciones municipales y a los cabildos insulares de los españoles residentes en el extranjero puesto que, tras las modificación de la LOREG realizada en el año 2011, para poder ejercer el derecho de sufragio activo en dichos comicios es necesaria la inscripción en el censo de españoles residentes en España. Además, el Gobierno de Canarias afirmaba que estas modificaciones de la LOREG violaban determinadas disposiciones tanto de la CE (sobre el padrón de españoles residentes en el extranjero, y en relación con las elecciones a los cabildos insulares) como de su propio Estatuto de autonomía (respecto de los derechos políticos de los canarios residentes en el extranjero). El TC desestimó este recurso de inconstitucionalidad, y, para ello, se apoyó, entre otras cuestiones, en el hecho de que el censo electoral «es concebido como un instrumento esencial para la ordenación del derecho de sufragio» [STC 86/2003, de 8 de mayo, FJ 6; STC 153/2014, de 25 de septiembre, FJ 3.b)], siendo «indispensable la inscripción en el mismo para ejercer el derecho» de sufragio. Asimismo, el TC afirma que el legislador electoral es al que le corresponde determinar las condiciones referidas al ejercicio del derecho de sufragio [FJ 3.b)].

7. Por lo que se refiere a los derechos de los extranjeros, cabe mencionar una sentencia del TS que, sin duda, es de los pronunciamientos más destacados de este tribunal durante el semestre objeto de atención en la presente crónica, y que se refiere a la doctrina jurisprudencial que sentó en relación con el valor de los documentos que porte un menor no acompañado en caso de discrepancia con su realidad física (ROJ: STS 3818/2014, de 23 de septiembre). Esta sentencia ha sido seguida por la publicación, solamente un día más tarde, de otra sentencia de este mismo tribunal (ROJ: STS 3817/2014, de 24 de septiembre). Todo ello será objeto de un comentario más detallado en el apartado 3.6 de esta crónica. Otra resolución, esta vez del Juzgado de Primera Instancia e Instrucción núm. 2 de Melilla, de 11 de septiembre de 2014, será objeto de un análisis particularizado en el apartado 3.7 de esta sección, trata de las llamadas «devoluciones en caliente» de ciudadanos extranjeros a Melilla, que tanto han ocupado la atención de los medios de comunicación en los últimos meses. Una de las cuestiones más controvertidas ha sido, como veremos más adelante en dicho comentario, determinar si los migrantes que se habían saltado la valla de Melilla habían llegado o no a entrar en suelo español y, por tanto, si se les iba a aplicar o no la legislación española de extranjería. Mencionar, asimismo, la STSJ de Madrid (Sala de lo Contencioso-Administrativo, Sección 1. a), núm. 926/2014, de 9 de julio (ROJ: STSJ M 7534/2014), en la que fue desestimado el recurso interpuesto contra la resolución del Consulado General de España en Bogotá, de 26 de noviembre de 2013, mediante la que le había sido denegado a la recurrente una solicitud de visado de reagrupación familiar en régimen comunitario. En esta sentencia se analizan varias disposiciones del Real Decreto 240/2007, de 16 de febrero, sobre entrada, libre circulación y residencia en España de ciudadanos de los Estados miembros de la Unión Europea y de otros Estados parte en el Acuerdo sobre el Espacio Económico Europeo (BOE núm. 51, de 
28 de febrero de 2007), así como del CEDH y del Derecho derivado de la UE en esta materia, y se cita jurisprudencia del TS, del TEDH y del TJUE existente en relación con la problemática de la reagrupación familiar.

8. La AN ha dictado diversas sentencias en relación con la apatridia, estimando los recursos interpuestos con el consiguiente reconocimiento de dicho estatuto (entre otros, ROJ: SAN 3290/2014, de 17 de julio; ROJ: SAN 3838/2014, de 16 de octubre; ROJ: SAN 3841/2014, de 16 de octubre; ROJ: SAN 4390/2014, de 20 de noviembre). A título de ejemplo cabe citar la sentencia de la Sala de lo Contencioso-Administrativo, de 30 de octubre (ROJ: SAN 4025/2014), en la que el demandante aduce haber nacido en un campamento de refugiados, en el departamento de Tinduf, y que, por tanto, carece de nacionalidad. En este asunto, la Sala establece, separándose del criterio del Abogado del Estado, «que no alcanza a entender cómo puede el citado certificado (se alude a la no presentación por el recurrente del certificado de MINURSO que acredite su procedencia de los campamentos de Tinduf) erigirse en presupuesto esencial para la concesión del estatuto de apátrida, hasta el punto de constituirse — siempre según el representante de la Administración- en una suerte de conditio sine qua non para el reconocimiento del derecho» (FJ 2), concluyendo la Sala que en este asunto "sí constan los datos que reflejan la concurrencia del presupuesto previsto en la norma: el demandante ha presentado varios documentos expedidos por la autoridad saharaui que ponen de manifestó que su nacionalidad es saharaui y que ha residido hasta el 10 de abril de 2012 en los campamentos de refugiados [...] y que además por oficio remitido por la Embajada de Argelia en Madrid se hace constar que el recurrente no ostenta la nacionalidad argelina», por lo que "procede reconocer al demandante el derecho solicitado» (FJ 3).

9. En relación con las cuestiones referidas al terrorismo, el Juzgado Central de Instrucción núm. 5 de la AN ha dictado el 9 de diciembre (núm. de recurso 5/2014) un auto de procesamiento en el que imputa a 15 yihadistas por un presunto delito de pertenencia o integración en organización terrorista por captar y adoctrinar a combatientes y miembros del grupo en la mezquita de la M-30 de Madrid. También cabe apuntar que la AN ha adoptado, en diciembre de 2014, una serie de autos relativos al cómputo de penas de históricos presos etarras. Estos autos, que serán objeto de comentario en la próxima crónica de la $R E D I$, destacan porque, si bien la Sección 1. a de la AN solicita a la Fiscalía que realice un nuevo cómputo de penas teniendo en cuenta sus periodos de reclusión en Francia, sin embargo, la Sección 2. ${ }^{a}$ ha adoptado una decisión contraria y ha denegado la petición de la defensa relativa a la acumulación de penas fruto de una interpretación dispar de la Decisión Marco 2008/675/JAI del Consejo, de 24 de julio, relativa a la consideración de las resoluciones condenatorias entre los Estados miembros de la Unión Europea con motivo de un nuevo proceso penal, y de la Decisión Marco 2008/315/JAI, de 26 de febrero de 2009, relativa a la organización y al contenido del intercambio de información de los registros de antecedentes penales entre Estados miembros.

10. En el ámbito del Derecho del mar, el TC ha tenido que pronunciarse sobre un nuevo conflicto positivo de competencia planteado por el Gobierno de Canarias, esta vez en relación con el Real Decreto 1485/2012, de 29 de octubre, que modificó el Real Decreto 1028/2007, de 20 de julio, por el que se establece el procedimiento administrativo para la tramitación de las solicitudes de autorización de instalaciones de generación eléctrica en el mar territorial, para adaptarlo a la nueva denominación y estructura de los departamentos ministeriales. Se trata de la STC 121/2014, de 17 de julio, en la que el TC ha aplicado su doctrina previamente establecida, por un lado, 
en las SSTC 8/2013, de 17 de enero, 87/2013, de 11 de abril, y 99/2013, de 23 de abril (que ya han sido objeto de atención en esta Revista, vol. LXV, 2013, núm. 2; véase el comentario realizado por la Prof. ${ }^{a}$ Rosa M. FeRnández EgEA), y, por otro lado, en las SSTC 3/2014, de 16 de enero, y 25/2014, de 13 de febrero [que han sido objeto de un análisis particularizado en el anterior número de esta Revista (vol. LXV, 2014, núm. 2; véase el comentario realizado por la Prof. ${ }^{a}$ Gabriela A. OANTA]. También en la STC 121/2014, de 17 de julio, el TC ha desestimado el conflicto positivo de competencia planteado, reiterando «de manera concluyente que el territorio autonómico no se extiende al mar territorial [...] y que el Estatuto de la Comunidad Autónoma de Canarias no contiene ninguna singularidad al respecto» [FJ 2.a)], y recordando, también, que ya había descartado que el mar territorial formase parte del territorio de dicha Comunidad Autónoma [FJ 2.a)].

11. Por lo que se refiere a la gran familia de los derechos humanos y las libertades fundamentales cuya protección ha vuelto a ocupar, también durante este semestre, gran parte de la actividad de los órganos judiciales españoles, cabe destacar, ya de entrada, el Acuerdo del Pleno del TS, de 21 de octubre de 2014, como cauce para ejecutar las sentencias del TEDH en tanto no exista todavía en el Ordenamiento jurídico español una disposición normativa que permita garantizar su efectividad, y al que dedicaremos un comentario detallado en el apartado 3.8 de esta crónica.

12. Y, descendiendo, ahora, al tratamiento particularizado de los derechos humanos y de las libertades fundamentales, cabe referirse a la atención prestada por el TC en relación con la supuesta vulneración de los derechos a la igualdad y a no padecer discriminación por razón de orientación sexual. Así, este tribunal ha desestimado cuatro recursos de amparo en los que se solicitaba la concesión de una pensión de viudedad al supérstite de una unión sexual. En las cuatro sentencias _las SSTC 115/2014 y 116/2014, de 8 de julio, la STC 124/2014, de 21 de julio, y la STC 157/2014, de 6 de octubre- el TC aplicó la doctrina establecida en esta materia mediante las SSTC 92/2014 y 93/2014, de 10 de junio, a la que nos referimos en la anterior crónica de jurisprudencia española en materia de DIP realizada por esta Revista (vol. LXVI, 2014, núm. 2, p. 176). Mencionar, asimismo, que las cuatro sentencias contaron con al menos un voto particular discrepante suscrito por uno o varios magistrados, que recogieron la argumentación plasmada en su momento por el Pleno del TC con ocasión de la STC 92/2014, de 10 de junio.

13. En la anterior crónica de jurisprudencia española en materia de DIP realizada por esta Revista analizamos detalladamente la STC 35/2014, de 27 de febrero, respecto de la supuesta vulneración de los derechos a la libertad personal y a la tutela judicial efectiva (vol. LXVI, 2014, núm. 2; véase el comentario realizado por la Prof. ${ }^{\text {a }}$ Gabriela A. OANTA). En dicho comentario, se presentaba la nueva doctrina del TC en relación con la posible aplicación del doble cómputo del tiempo de privación de libertad en el supuesto de un cumplimiento acumulado de varias penas cuando se habia establecido un limite máximo de cumplimiento de condena, y se adelantaba que las trece sentencias posteriores a la publicación de esta sentencia, solamente en el periodo comprendido entre los meses de enero y junio de 2014, llevaban a pensar que el TC iba a tener la posibilidad de aplicar esta doctrina nuevamente en el caso de otros recursos de amparo. Así ha ocurrido en el semestre de crónica jurisprudencial objeto ahora de nuestra atención, en concreto en la STC 117/2014, de 8 de julio.

14. En relación con la posible vulneración de la libertad ideológica y religio$s a$ prevista en el art. $16 \mathrm{CE}$, que ha dado lugar a resoluciones, cabe destacar las SSTC 140/2014, de 11 de septiembre, y 151/2014, de 25 de septiembre. Así, por lo que 
se refiere a la STC 140/2014, de 11 de septiembre, hay que mencionar que se trata de un recurso de amparo promovido por una persona que había sido despedida como profesora de Religión y Moral Católica en diversos centros de educación primaria de la Comunidad Autónoma de Canarias. Teniendo en cuenta las alegaciones presentadas tanto por la recurrente como por el Abogado del Estado y el Ministerio Fiscal, el TC decidió analizar la eventual vulneración del derecho a la no discriminación (art. $14 \mathrm{CE}$ ) en relación con el derecho a la libertad ideológica y religiosa (art. 16.1 $\mathrm{CE}$ ) unido al hecho de haber contraído matrimonio con un divorciado, con el derecho a la huelga (art. 28.2 CE), y con el derecho a la tutela judicial efectiva (art. $24 \mathrm{CE}$ ). En este asunto, el TC reitera los argumentos utilizados en su Sentencia 38/2007, de 15 de febrero, que fueron reiterados posteriormente en distintas ocasiones (por ejemplo, las SSTC 80/2007 a 90/2007, de 19 de abril, la STC 128/2007, de 4 de junio, etc.), mediante los cuales fueron encontrados conformes con la CE los párrs. 1 y 2 del art. III del Acuerdo entre el Estado español y la Santa Sede, de 3 de enero de 1979, sobre enseñanza y asuntos culturales, ratificado por España el 4 de diciembre de 1979. Según este artículo, los profesores de Religión y Moral Católica no podrán ser contratados indefinidamente, sino por una duración determinada, y sobre la base de un nombramiento o designación de carácter anual. Si bien las confesiones religiosas disponen de la libertad para establecer los contenidos de las enseñanzas religiosas y los criterios de cualificación que ha de reunir una persona para ser contratada como profesor(a) de religión, dicha libertad no es absoluta, siendo sujeta a las exigencias de la CE (FJ 5). El TC decidió denegar el amparo solicitado tras haber constatado que no existía un panorama indiciario suficiente que permitiera deducir que «la decisión de no contratar a la demandante de amparo un nuevo curso escolar estuviese conectada causalmente con el ejercicio por ésta de derechos fundamentales» (FJ 10). En relación con ello, hay que mencionar que el art. III del Acuerdo entre el Estado español y la Santa Sede sobre enseñanza y asuntos culturales, firmado en el año 1979, ha sido invocado, también, en el marco de la STSJ de las Islas Baleares (Sala de lo Social, Sección 1.a) núm. 312/2014, de 23 de septiembre (ROJ: STSJ BAL 774/2014) pronunciada sobre un recurso de súplica interpuesto contra la Sentencia de 26 de marzo de 2014 del Juzgado de lo Social núm. 1 de Ciutadella de Menorca que había enfrentado a la demandante, que había sido profesora de la asignatura de Religión y Moral Católica, contra la Conferencia Episcopal Española. En cuanto a la STC 151/2014, de 25 de septiembre, sobre un recurso de inconstitucionalidad interpuesto por más de 50 diputados del Grupo Parlamentario Popular del Congreso de los Diputados respecto de la Ley Foral de Navarra 16/2010, de 8 de noviembre, sobre la creación del registro de profesionales en relación con la interrupción voluntaria del embarazo, este Tribunal estimó parcialmente el recurso de inconstitucionalidad planteado al declarar inconstitucional y nulo el inciso del art. 5 de la mencionada Ley Foral de Navarra que regula el régimen de acceso a la información contenida en el registro de profesionales que objetan a la práctica del aborto. Este Tribunal entendió que al preverse que "podrán acceder» a la información contenida en este registro "aquellas personas que autorice expresamente la persona titular de la Gerencia del Servicio Navarro de Salud-Osasunbidea, en ejercicio legítimo de sus funciones» se establecía una legitimación muy amplia para tener acceso a una información de estas características, que es parte del contenido del derecho fundamental garantizado en el art. 16.1 CE.

15. La supuesta vulneración de los derechos a la imparcialidad judicial, la prueba, a conocer la acusación y a la presunción de inocencia ha sido analizada con detenimiento en la STC 133/2014, de 22 de julio, con ocasión de un recurso de amparo promovido por cuatro personas que habían sido condenadas con anterioridad por la Sala 
de lo Penal del TS y de la AN por un delito de pertenencia a organización terrorista. El derecho a la imparcialidad judicial ha representado una de las cuestiones más destacadas planteadas en la presente sentencia puesto que una de las magistradas del TC había sido recusada por falta de imparcialidad en un proceso anterior seguido contra uno de los recurrentes por enaltecimiento del terrorismo. En relación con ello, cabe mencionar que el derecho a la imparcialidad judicial está previsto en el art. 6.1 $\mathrm{CEDH}, \mathrm{y}$, en el ámbito nacional, aparece recogido implícitamente en el derecho a un proceso con todas las garantías estipulado en el art. $24.2 \mathrm{CE}$, disponiendo de una importancia trascendental en el terreno penal. De ahí que no sea de extrañar que el TC haya prestado especial atención a esta cuestión en la presente sentencia, y haya hecho una presentación detallada de la doctrina del TEDH sobre el art. 6.1 CEDH (FJ 3). Así, se presenta detalladamente la STEDH de 15 de octubre de 2009, Micallef c. Malta, en la que este Tribunal se remite a numerosos posicionamientos suyos en relación con la imparcialidad judicial [entre otras, Kyprianou c. Chipre (2005), De Cubber c. Bélgica (1984), Fey c. Austria (1993), Wettstein c. Suiza (1996), Moznaric c. Croacia (2005), etc.], y, asimismo, hace hincapié en la necesidad de distinguir entre, por un lado, la imparcialidad subjetiva — esto es, que el juez no haya mantenido relaciones indebidas con las partes; esta imparcialidad del juez será presumida hasta que haya pruebas de lo contrario-, y, por otro lado, la imparcialidad objetiva —es decir, asegurar que el juez se acerca al objeto del proceso sin haberse posicionado con anterioridad en relación con las cuestiones planteadas en el asunto- - Si bien, tal y como lo afirmó el TEDH en el asunto Kyprianou c. Chipre (punto 119), no existe una división hermética entre las dos formas de la imparcialidad judicial. En la Sentencia Micallef c. Malta (punto 98) el TEDH incluso llegó a reiterar que también tendrían que tenerse en cuenta las apariencias pues «la justicia no sólo debe realizarse, también debe verse que se realiza» (De Cubber c. Bélgica, punto 26), y que "debe retirarse cualquier juez sobre el que recaiga una legítima razón para temer una falta de imparcialidad» [Algar c. España (1988), punto 45]. Finalmente, el TC estimó en su Sentencia 133/2014, de 22 de julio, que no se había demostrado la existencia de dudas en relación con la imparcialidad judicial de la magistrada en relación con uno de los recurrentes y tampoco se aportaron nuevos elementos que permitiesen apreciar una pérdida de imparcialidad hacia uno de los recurrentes. De lo contrario, se llegaría a «emitir un inadmisible juicio universal de parcialidad carente del menor fundamento» (STC 133/2014, de 22 de julio, FJ 5). Respecto de esta opinión expresada por el TC en relación con el derecho a la imparcialidad judicial, una magistrada de este Tribunal se manifestó en un Voto particular en un sentido opuesto, es decir consideraba que el recurso de amparo solicitado tenía que haber sido estimado puesto que, entre otras cuestiones, existían dudas acerca de la imparcialidad de la magistrada del TC que había sido recusada por falta de imparcialidad en un proceso anterior seguido contra uno de los recurrentes por enaltecimiento del terrorismo (punto 2). En relación con ello, se cita, por una parte, la STEDH de 5 de febrero de 2009, Olujic c. Croacia, en la que se afirmó que se justificaba objetivamente el que un acusado desconfiase de la imparcialidad de aquel juez que había manifestado la formación de una vista desfavorable sobre el asunto que tuviesen pendiente, y, por otra parte, la STEDH de 16 de septiembre de 1999, Buscemi c. Italia, en la que se estimó que los jueces tenían que «garantizar su imagen de jueces imparciales» en aquellos asuntos que tenían pendiente resolver (punto 1). Finalmente, mencionar que la supuesta vulneración del derecho a la presunción de inocencia prevista en el art. 24.2 CE que también fue invocada en este asunto fue desestimada por el TC al considerarse que la condena de los recurrentes había sido «respetuosa con la doctrina constitucional sobre la posibilidad de condenas basadas en prueba indiciaria y la necesidad de que sean debidamente ponderados los argumentos 
de descargo» (STC 133/2014, de 22 de julio, FJ 10). Este posicionamiento del TC ha sido reiterado dos meses más tarde en la STC 146/2014, de 22 de septiembre, en el marco de un recurso de amparo promovido en relación con una supuesta vulneración del derecho a la presunción de inocencia.

16. En relación con la protección del interés superior del menor, hay que señalar la publicación de diversas sentencias por parte del TS (entre otras, ROJ: STS 2940/2014, de 15 de julio; ROJ: STS 4072/2014, de 20 de octubre; ROJ: STS 4243/2014, de 27 de octubre; ROJ: STS 5099/2014, de 11 de diciembre), y que, a su vez, han dado lugar a la aplicación en reiteradas ocasiones de la Convención sobre los Derechos del Niño (ROJ: ATS 7304/2013, de 10 de julio; ROJ: STS 3916/2014, de 14 de octubre; ROJ: STS 3435/2014, de 10 de julio; ROJ: STS 3916/2014, de 14 de julio; ROJ: STS 5099/2014, de 11 de diciembre, entre otras). Esta misma materia ha sido objeto de atención también por parte de la AP de A Coruña (Sección 3. ${ }^{a}$ ) en su Sentencia núm. 297/2014, de 10 de octubre, en la que el juez se ha apoyado, entre otros, en distintas disposiciones de la Convención sobre los Derechos del Niño, la Carta Europea de los Derechos del Niño, la Carta de los Derechos Fundamentales de la UE, y alguna resolución del Parlamento Europeo, para hacer hincapié en el reconocimiento del derecho a la comunicación del progenitor con el hijo del que se beneficia en la actualidad todo menor (FJ 4). Prosiguiendo con los derechos de los niños amparados por el DIP, cabe mencionar la SAP de Badajoz (Sección 3. ${ }^{\text {) }}$ núm. 230/2014, de 2 de octubre, en la que se menciona el art. 12.1 de la Convención sobre los Derechos del Niño relativo al derecho del niño a expresar su opinión libremente en todos aquellos asuntos que le afectaran, teniéndose en cuenta su opinión en función de la edad y la madurez que tenga. En relación con ello, indicar que este derecho es reconocido, igualmente, por la Convención europea para el ejercicio de los derechos de los niños y otros documentos adoptados en el marco del Consejo de Europa, y por la Carta de los Derechos Fundamentales de la UE, entre otros.

17. El fracking y el derecho a la salud humana han ocasionado dos nuevas sentencias del TC en relación con sendos recursos de inconstitucionalidad interpuestos por el Gobierno de España en contra, por un lado, de la Ley del Parlamento de La Rioja 7/2013, y, por otro lado, de la Ley Foral 30/2013 del Parlamento de Navarra - se trata de la STC 134/2014, de 22 de julio, y la STC 208/2014, de 15 de diciembre-. Mediante estos actos normativos, se prohibía la fractura hidráulica como técnica de investigación y extracción de gas no convencional en el territorio de la Comunidad Autónoma de La Rioja y de la Comunidad Autónoma de Navarra, respectivamente. En las dos sentencias el TC ha tenido la oportunidad de aplicar su doctrina iniciada con la innovadora STC 106/2014, de 24 de junio, que fue objeto ya de análisis en la anterior crónica de jurisprudencia española en materia de DIP realizada por esta Revista (vol. LXVI, 2014, núm. 2; véase el comentario realizado por la Prof. a Gabriela A. OANTA), y en la que este Tribunal ha considerado nulas las dos leyes autonómicas cuestionadas que prohibían absoluta e incondicionalmente el fracking en el territorio de dichas Comunidades Autónomas.

18. Sobre el derecho de control sobre los datos relativos a la propia persona y el derecho al honor se ha pronunciado la AP de Albacete (Sección 2. ${ }^{\text {a) }}$ en su Sentencia núm. 140/2014, de 7 de julio, en relación con un recurso de apelación interpuesto por la empresa Telefónica Móviles España SAU en contra de la sentencia del Juzgado de Primera Instancia núm. 4 de Albacete, de 8 de mayo de 2013, que había declarado improcedente la inclusión de la empresa Area Proyect Solutions, S. L., en el registro de la morosidad al entender éste que dicho acto había constituido una intromisión 
ilegítima en su honor. La AP de Albacete (Sección 2. ${ }^{\text {) }}$ ) decidió desestimar el recurso interpuesto por la empresa Telefónica Móviles España SAU: entendía que la inclusión de los datos personales de la empresa afectada en el registro de morosidad era ilícita al ser contraria a la normativa de protección de datos. En este sentido, este tribunal se apoyó en distintos instrumentos convencionales internacionales sobre derechos humanos, como el Convenio núm. 108 del Consejo de Europa para la protección de las personas con respecto al tratamiento automatizado de datos de carácter personal, y la Carta de Derechos Fundamentales de la UE. Y, asimismo, destacó la Directiva 1995/46/CE (de 24 de octubre, del Parlamento Europeo y del Consejo, de protección de las personas físicas en lo que respecta al tratamiento de datos personales y a la libre circulación de estos datos, DO L 281, de 23 de noviembre de 1995, pp. 31-50) y su influencia en el Ordenamiento jurídico español en este campo.

19. Como advertíamos, también durante el segundo semestre del año 2014 la jurisprudencia del TEDH y en relación con determinadas disposiciones del CEDH ha tenido una gran presencia en la actividad del TC. En este sentido, cabe referirse, además de los pronunciamientos del TC ya mencionados con anterioridad que incluyen referencias bien al TEDH o bien al CEDH, a sobre todo los siguientes asuntos:

- Un recurso de amparo en relación con una supuesta vulneración de los derechos a la intimidad, a la protección de datos de carácter personal, a un proceso con todas las garantías y a la presunción de inocencia en el contexto de la obtención de una muestra de ADN de una frotis bucal practicada por la Policía con consentimiento del afectado (STC 135/2014, de 8 de septiembre). En esta sentencia, el TC volvió a reiterar tanto su propia doctrina aplicada en distintas sentencias pronunciadas en el primer semestre del año 2014, que han sido objeto de un análisis particularizado en el anterior número de esta Revista (vol. LXV, 2014, núm. 2; véase el comentario realizado por la Prof. a Joana ABRISKETA URIARTE), como la jurisprudencia del TEDH que considera que «el derecho a la vida privada resulta ya comprometido por la mera conservación y almacenamiento de muestras biológicas y perfiles de ADN». En relación con ello, el TC hace hincapié sobre todo en la decisión de inadmisión del TEDH, de 7 de diciembre de 2006, en el asunto Van der Velden c. Países Bajos en la que el Tribunal de Estrasburgo consideró que la obtención de una muestra de estas características puede interpretarse como una intromisión en la intimidad de la persona afectada, pudiendo ser, además, considerada invasiva y, por tanto, representar una intromisión en la vida privada en el sentido del art. 8.1 CEDH (FJ 2). Finalmente, el TC desestimó el presente recurso.

- Seis recursos de inconstitucionalidad acumulados que dieron lugar a la STC 141/2014, de 11 de septiembre, que fueron interpuestos por los respectivos Consejos de Gobierno de Madrid y de La Rioja, y por más de 50 diputados del Grupo Parlamentario Popular del Congreso y el Gobierno de Canarias contra determinadas disposiciones de la Ley 8/2007, de 28 de mayo, y del texto refundido de la Ley de suelo, aprobado por Real Decreto legislativo 2/2008, de 20 de junio. Tanto los demandantes como el propio TC se apoyan en distinta jurisprudencia del TEDH en relación, por ejemplo, con el art. 1 del Protocolo adicional primero del CEDH (STEDH de 9 de diciembre de 1994, Holy Monasteries; STEDH de 8 de julio de 1986, Lithgow y otros), y con el principio según el cual debe existir un equilibrio proporcional entre el daño sufrido y la indemnización correspondiente (STEDH de 24 de abril de 2003, Yiltas Yildiz Turistik Tesisleri A.S. c. Turquía; STEDH de 6 de diciembre de 2011, Anastasakis c. Grecia) (véanse los Antecedentes y el FJ 9 de la STC 141/2014, de 11 de septiembre). En relación con ello, hay que mencionar que el Magistrado Juan José González Rivas formuló un Voto particular respecto de esta STC 141/2014 al no estar de acuerdo con algunas distinciones que el TC realiza en esta sentencia, y, para ello, se apoya en algunas 
sentencias del TEDH (por ejemplo, la STEDH de 9 de octubre de 2003, Federici c. Italia; la STEDH de 28 de noviembre de 2002, Ex Rey de Grecia y otros c. Grecia). Finalmente, el TC desestimó parcialmente los recursos acumulados interpuestos pues estimó que algunas impugnaciones habían perdido objeto, que otras disposiciones de la Ley de suelo eran inconstitucionales, y la mayor parte de lo demandado fue desestimado.

- Un recurso de amparo promovido en relación con la supuesta vulneración del derecho al secreto de las comunicaciones previsto en el art. 18.3 CE tras haber sido realizadas grabaciones de las escuchas telefónicas efectuadas en dependencias policiales, y a modo derivado, también respecto de la supuesta vulneración del derecho a la tutela judicial efectiva, a la presunción de inocencia y a un proceso con todas las garantías estipuladas en el art. 24.2 CE (STC 145/2014, de 22 de septiembre). El TC estimó parcialmente este recurso de amparo, solamente por lo que se refiere a la violación del art. 18.3 CE y, por tanto, declaró nula la prueba que había sido obtenida en las dependencias policiales sin el consentimiento del afectado. Para llegar a esta conclusión, el TC se apoyó en una amplia jurisprudencia del TEDH relativa al art. $8 \mathrm{CEDH}$ (véanse, entre otras, la STEDH de 2 de agosto de 1984, Malont; la STEDH de 30 de julio de 1998, Valenzuela c. España; SSTEDH de 24 de abril de 1990, Kruslin c. Francia y Huvig c. Francia).

- Un recurso de amparo causado en relación con la supuesta vulneración de los derechos a la tutela judicial efectiva, a la defensa y a la presunción de inocencia como consecuencia de unas declaraciones autoinculpatorias prestadas en diligencias policiales realizadas por los dos solicitantes de amparo (STC 165/2014, de 8 de octubre). En esta ocasión, el TC mencionó algunas sentencias del TEDH para fundamentar su decisión de desestimar el recurso planteado, en las que se había afirmado el carácter absoluto de las disposiciones del art. $3 \mathrm{CEDH}$ sobre la prohibición de la tortura y de las penas o los tratos inhumanos o degradantes (STEDH de 1 de junio de 2010, Gäfgen c. Alemania, punto 178) a diferencia del art. $6 \mathrm{CEDH}$ que prevé el derecho de toda persona a un proceso equitativo, sin regular, sin embargo, la admisibilidad de los medios de prueba que le compete al legislador nacional de cada Estado. El TC, en línea con el TEDH, considera que no constituye una violación del art. 6 CEDH la utilización de las declaraciones efectuadas durante la fase de instrucción preparatoria, siempre y cuando los derechos de la defensa estén respetados, como fue el caso de los dos solicitantes de amparo que ocasionó este asunto del TC (STC 165/2014, FJ 4; STEDH de 27 de febrero de 2001, Luca, punto 40; STEDH de 20 de noviembre de 1989, Kostovski c. Holanda, STEDH de 19 de diciembre de 1990, Delta c. Francia; STEDH de 26 de abril de 2001, Asch c. Austria).

- Un recurso de amparo planteado en relación con la supuesta vulneración del derecho a la tutela judicial efectiva sin indefensión, en su vertiente de acceso al recurso (STC 179/2014, de 3 de noviembre). El TC estimó el recurso pues encontró que la declaración desierta del recurso de apelación interpuesto por el interesado ante el TSJ de Canarias frente a la sentencia condenatoria de la AP de Las Palmas, recaída en proceso de Tribunal de Jurado, como consecuencia de la personación extemporánea de la procuradora designada de oficio del acusado para actuar ante el Tribunal de apelación, permitía afirmar que el órgano jurisdiccional no había velado lo suficiente por la efectividad de la asistencia del acusado. Es doctrina asentada tanto del TC (STC 47/2003, de 3 de marzo, FJ 2; STC 179/2014, de 3 de noviembre, FJ 3) como del TEDH (entre otras: STEDH de 9 de octubre de 1979, Airey; STEDH de 13 de mayo de 1990, Ártico; STEDH de 17 de julio de 2007, Bobek; STEDH de 5 de julio de 2012, Szubert) que la defensa del acusado o del condenado en el proceso penal por parte de profesionales designados de oficio debe ser efectiva, que no es suficiente el nombramiento de un abogado, sino que se debe garantizar una verdadera asistencia que le permita el acceso a la justicia. 
- Un recurso de inconstitucionalidad interpuesto por más de cincuenta diputados en relación con distintos preceptos de la Ley 22/2007, de 18 de diciembre, de farmacia de Andalucía (STC 181/2014, de 6 de noviembre de 2014). El TC utiliza algunos de los posicionamientos del TEDH en relación con el alcance y la aplicación de los arts. 6 y 7 CEDH (STEDH de 21 de febrero de 1984, Öztürk; STEDH de 22 de mayo de 1990, Weber; STEDH de 27 de agosto de 1991, Demicoli). Así, este Tribunal subraya que si los Estados pudieran clasificar a una infracción como administrativa en lugar de penal ello significaría que la aplicación de los arts. 6 y 7 quedaría subordinada a la voluntad soberana de dichos Estados. Lo que "podría conducir a unos resultados incompatibles con el objetivo y la finalidad del CEDH» (STC 181/2014, de 6 de noviembre, FJ 5). Además, «el carácter limitado de la cuantía de la sanción no es un factor decisivo para excluir una infracción de la aplicabilidad del art. $6 \mathrm{CEDH}$ », a diferencia de "la función que pretende conseguirse a través de la imposición de la medida restrictiva» (STC 181/2014, de 6 de noviembre, FJ 6).

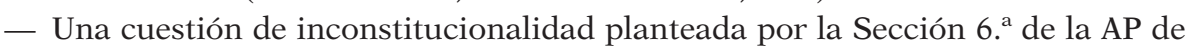
Barcelona en relación con la interpretación conforme a la CE del precepto legal relativo a la reiteración de las faltas de hurto. En su Sentencia 185/2014, de 6 de noviembre, el TC aplica la interpretación del art. 6.2 CEDH relativo al principio de presunción de inocencia (entre otras, STEDH de 24 de mayo de 2011, Konstas c. Grecia, puntos 35 y 36) para desestimar la cuestión de inconstitucionalidad planteada al considerar que «la presunción de inocencia no puede dejar de aplicarse en procedimientos de recurso simplemente porque el acusado fue condenado en primera instancia»; en caso contrario ello «significaría la inaplicación de la presunción de inocencia en los procedimientos cuyo objetivo es la revisión del caso y la revocación de la condena previa» (STC 185/2014, de 6 de noviembre, FJ 6).

- Un recurso de amparo promovido en relación con la vulneración de los derechos a un proceso con todas las garantías y a la presunción de inocencia, ocasión en la que el TC en su Sentencia 191/2014, de 17 de noviembre, ha recordado la doctrina del TEDH que siguió a partir del año 2002 (STEDH de 29 de octubre de 1991, Jan Ake Andersson c. Suecia; STEDH de 5 de diciembre de 2002, Hoppe c. Alemania), y según la cual el respeto de los principios de publicidad, inmediación y contradicción forman parte del derecho a un proceso con todas las garantías previsto en el art. 24.2 CE. De ahí que toda condena necesitase fundamentarse en una actividad probatoria y en un debate público en el que se respete la posibilidad de contradicción (FJ 3).

20. En relación con las obligaciones convencionales contraídas por España, debe resaltarse, por un lado, la STC 119/2014, de 16 de julio, sobre un recurso de inconstitucionalidad interpuesto por el Parlamento de Navarra en relación con la Ley 3/2012, de 6 de julio, de medidas urgentes para la reforma del mercado laboral; y, por otro lado, la STSJ de Cataluña, Sala de lo Social, Sección 1. ${ }^{\text {a }}$, de 1 de julio de 2014 (ROJ: STSJ CAT 7887/2014), sobre un recurso de suplicación interpuesto frente a la sentencia del Juzgado Social núm. 33 de Barcelona, de 19 de noviembre de 2013, en la que se había declarado nulo el despido por fraude de ley y la vulneración de ciertos derechos fundamentales previstos en la CE de la parte demandante. En las dos resoluciones se cuestionaba la adecuación de la normativa española en esta materia con algunas normas convencionales asumidas por España, por ejemplo, en el marco de la Organización Internacional del Trabajo (OIT); ello será objeto de análisis individualizado en el apartado 3.8 de esta sección. La problemática de las normas convencionales mediante las que el Estado español se ha comprometido en el ámbito internacional también ha sido tratada, por un lado, en la SAP de Almería, Sección 3. a , núm. 115/2014, de 4 de julio (ROJ: SAP AL 695/2014) respecto del Convenio de Ginebra de 19 de mayo de 1956 
sobre Transporte Internacional de Mercancías por Carretera (CMR) al que España se adhirió el 12 de septiembre de 1973 ( $B O E$ de 7 de mayo de 1974); y, por otro lado, en la SAP de Cartagena, Sección 5. a, núm. 280/2014, de 22 de julio (ROJ: SAP MU 1301/2014), en relación con el Convenio Internacional de Torremolinos 1977/1993 que, debido al número reducido de ratificaciones por parte de los Estados, fue reemplazado por el Protocolo de 1993, por el que se establecen los requisitos mínimos de seguridad para la construcción, equipamiento y operación de los buques pesqueros con eslora igual o superior a 24 metros. Lo interesante respecto del Convenio Internacional de Torremolinos 1977/1993, a efectos de nuestra crónica, es que sus disposiciones son vinculantes a los Estados miembros de la UE, a pesar de no haber entrado en vigor todavía, pues su contenido fue recogido posteriormente por la Directiva 97/70/CE del Consejo, por el que se establece un régimen armonizado de seguridad para los buques de pesca de eslora igual o superior a 24 metros ( $D O$ L 34, de 9 de febrero de 1998, pp. 1-29).

21. También cabe referirse a la STC 113/2014, de 7 de julio, en la que este Tribunal se ha pronunciado sobre una orden europea de detención y entrega desde la perspectiva de una supuesta vulneración del derecho a la tutela judicial efectiva, a la defensa y a la asistencia letrada en el sentido del art. 24.1 y $2 \mathrm{CE}$.

22. Finalmente, hay que señalar que durante este cuatrimestre el TC ha vuelto a prestar especial y detallada atención al Derecho de la UE. Partiendo de la idea según la cual la crónica de jurisprudencia española en materia de DIP realizada por esta Revista no ha de ser el lugar donde se preste especial atención a la jurisprudencia del TC que aborda las cuestiones de Derecho de la UE, nos limitaremos a mencionar las sentencias del TC publicadas en relación con dos conflictos positivos de competencia y tres recursos de inconstitucionalidad. Se trata, en primer lugar, de dos conflictos positivos de competencia planteados por el Consejo de Gobierno de la Comunidad de Madrid y de Castilla y León, respectivamente, en relación con distintas disposiciones del Real Decreto 395/2007, de 23 de marzo, por el que se regula el subsistema de formación profesional para el empleo (SSTC 112/2014, de 7 de julio, y 176/2014, de 3 de noviembre); en segundo lugar, de un recurso de inconstitucionalidad interpuesto por el Gobierno de Cataluña respecto de los arts. 4 y 5 del Real Decreto-ley 1/2009, de 23 de febrero, de medidas urgentes en materia de telecomunicaciones (STC 142/2014, de 11 de septiembre); en tercer lugar, de un recurso de inconstitucionalidad promovido por el Parlamento de Cataluña en relación con la Ley 37/2003, de 17 de noviembre, del ruido; y, en cuarto lugar, de un recurso de inconstitucionalidad interpuesto por el Consejo de Gobierno de la Junta de Andalucía en relación con distintas disposiciones de la Ley 15/2012, de 27 de diciembre, de medidas fiscales para la sostenibilidad energética, el Real Decreto-ley 29/2012, de 28 de diciembre, de mejora de gestión y protección social en el sistema especial para empleados de hogar y otras medidas de carácter económico y social y del Real Decreto-ley 2/2013, de 1 de febrero, de medidas urgentes en el sistema eléctrico y en el sector financiero (STC 183/2014, de 6 de noviembre). Y, como es natural, también el TS ha tenido la ocasión de pronunciarse sobre múltiples asuntos en los que resultaba pertinente la aplicación de normas de la UE, como: la Directiva 2012/13/UE relativa al derecho a la información en los procesos penales (ROJ: STS 4961/2014, de 20 de noviembre), el Convenio de aplicación del Acuerdo Schengen y el principio non bis in ídem (ROJ: STS 4163/2014, de 10 de octubre), o la responsabilidad patrimonial del Estado por incumplimiento del Ordenamiento jurídico de la UE (ROJ: STS 4390/2014, de 3 de noviembre), entre muchas otras.

Gabriela A. OANTA

Universidade da Coruña

http://dx.doi.org/10.17103/redi.67.1.2015.3a.01 


\section{COMENTARIOS DE SENTENCIAS}

\subsection{El Sáhara Occidental: posibilidad de continuar instruyendo un proceso relativo a supuestas violaciones graves de derechos humanos}

Auto de la Audiencia Nacional (Sala de lo Penal, Sección 2. a), de 4 de julio de 2014 (ROJ: AAN 256/2014). Ponente: José Ricardo Juan de Prada Solaesa.

Referencia Centrode DocumentaciónJudicial(Id. Cendoj) 28079229912014200039.

1. Se ha dicho hace poco, por relación al pueblo saharaui, que «el sumatorio de capital político, social y jurídico internacional [que atesora] no ha rendido dividendos a un pueblo sujeto a un proceso de autodeterminación bajo imperativo de ius cogens [...]. Más bien al contrario, su estatus es el de un actor internacional exangüe por inanición institucional» [PALACios ROMERo, F., "De proceso ius cogens a coyuntura ius abutendi», en Palacios Romero, F. (coord.), El derecho a la libre determinación del pueblo del Sáhara Occidental, Navarra, Aranzadi, 2014, p. 48]. Resulta difícil discrepar de esta afirmación. El Sáhara Occidental es hoy el único territorio no autónomo del continente africano que permanece pendiente de descolonización, pese a que lleva medio siglo inscrito en la lista del Comité de los Veinticuatro, y la pasividad mostrada por la comunidad internacional frente a la vulneración del derecho a la libre determinación del pueblo saharaui por parte de la potencia ocupante (Marruecos) no hace presagiar cambios inminentes en el statu quo. Esta violación del derecho a la autodeterminación se encuentra íntimamente ligada, además, a una situación general de vulneración de los derechos humanos en el territorio que ha sido constatada por diversas fuentes; así, el ACNUDH ha indicado que «el respeto de todos los derechos humanos del pueblo del Sáhara Occidental debe ser considerado conjuntamente con este derecho [a la libre determinación] y la falta de su realización inevitablemente afectará al disfrute de todos los derechos garantizados en los siete tratados fundamentales de derechos humanos en vigor» (Report of the OHCHR Mission to Western Sáhara and the Refugee Camps in Tindouf, Ginebra, 8 de septiembre de 2006).

2. La respuesta proporcionada frente a esta situación por los mecanismos institucionales de control de los derechos humanos resulta, a todos los niveles, insatisfactoria. Los tribunales internos de la potencia ocupante han consagrado la impunidad de los responsables de las violaciones; desde el inicio de la invasión del Sáhara Occidental los tribunales marroquíes han dictado tan sólo una condena por vulneración de derechos humanos, en concreto por la muerte de un manifestante saharaui a manos de policías marroquíes en 2005 (cfr. Ruiz Miguel, C., "La responsabilité internationale et les droits de l'homme: le cas du Sáhara Occidental», Cahiers de la Recherche sur les Droits Fundamentaux, 2013, núm. 11, p. 111). Los mecanismos de control universales, ya sean convencionales o extraconvencionales, y regionales arrojan resultados muy débiles (GonzÁLEZ VegA, J., "El respeto de los derechos humanos en el Sáhara Occidental: cuestiones de derecho internacional», en El derecho a la libre determinación..., op. cit., en particular pp. 95-105). Y el eventual recurso a la jurisdicción penal internacional está descartado, al no ser parte Marruecos en el Estatuto de Roma y no aparecer en el horizonte de expectativas del CdS la constitución de un tribunal ad hoc o la remisión de la situación a la CPI. Ante este panorama, el control de las violaciones de derechos humanos a través de las jurisdicciones penales de terceros Estados mediante la activación del principio de jurisdicción universal ha sido, aun teniendo en cuenta las dificultades prácticas que implica, una de las escasas vías de respuesta 
frente a la situación de impunidad que existe en el Sáhara Occidental. En ese contexto se ubica, de forma específica, el auto objeto de comentario que responde - a mi juicio, de una manera sorprendente, unánime y mediante argumentos jurídicos que no comparto- a la pregunta de si la AN puede continuar instruyendo, tras la reforma del principio de jurisdicción universal operado por la LO 1/2014, de 13 de marzo, un proceso relativo a un supuesto de violaciones graves de los derechos humanos en el Sáhara Occidental.

3. En el Auto 40/2014, de 4 de julio, la Sección 2. ${ }^{\text {a }}$ de la Sala de lo Penal de la AN se ha pronunciado - en el contexto del Sumario 4/14, instruido por el JC núm. 1 del mismo órgano judicial, por delitos de lesa humanidad y genocidio- sobre la concurrencia de los requisitos previstos en el apartado a) del art. 23.4 de la LOPJ a los efectos de cumplir con el mandato previsto en la disposición transitoria de la LO 1/2014, de 13 de marzo. Como se recordará, en dicha transitoria se establece que «las causas que en el momento de entrada en vigor de esta ley se encuentren en tramitación por los delitos a los que se hace referencia en la misma quedarán sobreseídas hasta que no se acredite el cumplimiento de los requisitos establecidas en ella». El procedimiento en cuestión nace por dos querellas presentadas por la Liga Española Pro Derechos Humanos y por la familia del ciudadano español Baby Handay Buyema contra los ministros de Defensa, Interior y Asuntos Exteriores del Reino de Marruecos y contra el gobernador de la ciudad de El Aaiún por la actuación de las fuerzas de seguridad marroquíes contra los habitantes del asentamiento Gdeim Izik (Campamento de la Dignidad) instalado en las proximidades del Aaiún. Los hechos que se produjeron durante el desalojo (desapariciones, agresiones físicas, torturas, asesinatos) fueron calificados en las querellas como delitos de lesa humanidad, genocidio, asesinato, lesiones, torturas y secuestros, de los arts. 607 bis, 174, 175, 176, 177 y 139 del Código Penal. Marruecos nunca respondió a la Comisión Rogatoria librada en 2010 para conocer si existía algún procedimiento en curso sobre estos hechos, por lo que las querellas estaban en suspenso hasta que se dictó el auto ahora comentado; a consecuencia del mismo, las querellas han sido admitidas a trámite mediante Auto del JC núm. 2 de la AN, de 19 de septiembre de 2014.

4. La singularidad del Auto 40/2014, de 4 de julio, estriba en que el Pleno de la Sala, compartiendo el criterio defendido por el Ministerio Fiscal, ha considerado que «España de iure, aunque no de facto, sigue siendo la Potencia Administradora del territorio, y como tal, hasta que finalice el periodo de la descolonización, tiene las obligaciones recogidas en los arts. 73 y 74 de la Carta de Naciones Unidas, entre ellas dar protección, incluso jurisdiccional, a sus ciudadanos contra todo abuso, para lo cual debe extender su jurisdicción territorial para hechos como los que se refieren en la querella a que se contrae el presente procedimiento [por lo que] el juzgado de instrucción remitente de las actuaciones tiene jurisdicción para el conocimiento de los hechos objeto de querella en atención al criterio de territorialidad del art 23.1 de la LOPJ y no del de jurisdicción universal del art 23.4 de la LOPJ, por lo que no se ve afectado por la reciente reforma de dicho artículo» (FJ 1).

5. El nudo de los argumentos esgrimidos por la Fiscalía y asumidos por la Sala se apoya en el carácter nulo de los Acuerdos de Madrid. A partir de este dato, que resulta indiscutible, la Fiscalía concluye que «Naciones Unidas ha mantenido una posición uniforme [...] al dictaminar que el mismo es nulo, sin eficacia jurídica, en consecuencia siempre ha considerado a España como la Potencia administradora» (cursiva añadida). Aunque la premisa de la nulidad es cierta, la conclusión que se extrae resulta inexacta, a mi entender. Desde que el Gobierno español se desligó unilateralmente de 
su responsabilidad en la administración del territorio (Carta al SG de 26 de febrero de 1976, A/31/56, S/11997), ninguna resolución de la ONU ha declarado a España como Potencia administradora. El Dictamen Corell, citado en el auto comentado como aval de la tesis de que España continúa siendo Potencia administradora de iure, tampoco recoge esa afirmación sino que se limita a constatar que «el acuerdo de Madrid no transfirió la soberanía sobre el territorio, ni confirió a ninguno de los signatarios la condición de Potencia administradora, condición que España, por sí sola, no podía haber transmitido unilateralmente» (S/2002/161, núm. 7).

6. A partir de dichos elementos se puede afirmar: que Marruecos no es Potencia administradora (administering power) del territorio puesto que no tiene título para ello y no desarrolla las funciones que el art. 73 de la Carta enlaza a dicho estatuto, esto es, en esencia, la promoción de la libre determinación del pueblo que habita el territorio administrado; que Marruecos es la potencia ocupante, como afirman las resoluciones AGNU 34/37 y 35/19 y se deriva de la situación fáctica de control militar, así como que ha "administrado el territorio del Sáhara occidental por sí solo» (Dictamen Corell); que Marruecos vulnera el derecho de autodeterminación del pueblo saharaui; y que España ha violado las obligaciones que le sujetaban como Potencia administradora, al desistir de sus funciones y renunciar a la organización de un referéndum de autodeterminación.

7. Sin embargo, a partir de dichos elementos, considero bastante más difícil poder deducir, como hace el Auto 40/2014 de la AN, que España mantiene el estatuto de Potencia administradora de iure. Como ya se ha señalado al respecto, hace algunos años pero con un enfoque que permanece vigente, «no obstante la valoración jurídica que podamos mantener sobre los Acuerdos de Madrid [...] después de 26 años de ocupación del territorio por parte de Marruecos y a la vista de la idéntica posición, con muy pocos matices diferenciadores, mantenida por los sucesivos gobiernos españoles a este respecto, resulta poco riguroso a estas alturas sostener que España continúa siendo la Potencia administradora del Sáhara Occidental. Mutatis mutandis es como si en la actualidad le atribuyéramos al Reino Unido el estatuto de potencia mandataria de los territorios palestinos ocupados por Israel, cincuenta años después de que se retirara de los mismos» (FERRER LlORET, J., La aplicación del principio de autodeterminación de los pueblos: Sáhara Occidental y Timor Oriental, Alicante, Universidad de Alicante, 2002, pp. 40-41).

8. De igual modo, me parece frágil la conexión argumental que realiza la Fiscalía entre el reconocimiento de que España continúa siendo la Potencia administradora de iure del Sáhara Occidental y el establecimiento de la jurisdicción penal de nuestros tribunales sobre el mismo en virtud del principio de territorialidad. Aunque la Fiscalía se apoya en que «hay un importante sector doctrinal» que defiende este estatuto para España, lo cierto es que los análisis monográficos sobre la cuestión ponen el foco sobre las obligaciones políticas del Estado (a la hora de apoyar de forma proactiva la exteriorización de la voluntad de la población saharaui, en vez de mantener un enfoque de neutralidad equidistante) y, sobre todo, en las obligaciones de tipo económico, social y educativo, que alcanzarían a España y que debieran pasar por intentar evitar el expolio de las riquezas del Sáhara Occidental, o al menos no contribuir al mismo, por parte de la potencia ocupante [al respecto Ruiz Miguel, C., «Las obligaciones legales de España como potencia administradora del Sáhara Occidental», ADI, vol. 26, 2010, en concreto pp. 325-330; y Trillo, E., «Spain as Administering Power of Western Sáhara», en ARTS, K. y PINTO, P. (eds.), International Law and the Question of Western Sahara, Porto, IPJET, 2007]. La tesis de un eventual ejercicio de la jurisdicción pe- 
nal sobre la base del principio de territorialidad no se contempla, por tanto, en estos trabajos generales. De una manera ambigua, ya que se está hablando de dos procesos tramitados bajo el principio de jurisdicción universal, sí que aparece una referencia posterior a que «l'Espagne peut alors exercer sa juridiction sur le territoire non autonome qui est encore sous sa responsabilité» (en RuIz MigueL, C., "La responsabilité...», op. cit., p. 111). De manera más clara, sin embargo, la tesis de la territorialización del Sáhara que ha consagrado finalmente el Auto de la AN se plantea, aunque como mera hipótesis, en un último trabajo (FUNGAIRIÑo, E., «Los tribunales españoles y el Sáhara Occidental. Algunas sentencias», en Palacios Romeo, F., op. cit., p. 273, nota 11) que advierte también sobre «las dificultades que luego hubiesen surgido para llevar a cabo las diligencias de investigación (examen del lugar de los hechos, declaración de los inculpados marroquíes, declaración de los testigos, etc.)». Aviso, claro, válido para el proceso ahora en curso.

9. Para finalizar con el análisis del auto, me resta referirme a la quinta conclusión del escrito de la Fiscalía, que se incorpora íntegro al texto adoptado por la AN, en el que se indica que «debe señalarse por último que si por la legalidad internacional un territorio no puede ser considerado marroquí, tampoco puede aceptarse su jurisdicción como fuero preferente del lugar de comisión del delito». Me parece complicado hacer compatible esta afirmación, que no se argumenta en el auto, con el Derecho internacional aplicable a la situación del Sáhara, que debe ser determinado a partir de la existencia de una potencia ocupante que invade por la fuerza un territorio no autónomo que todavía no ha ejercido el derecho a la libre determinación, tras haber sido abandonado éste por la potencia administradora. Desde esa perspectiva, aunque no desarrollemos aquí la cuestión, entiendo que son aplicables a la población del territorio no autónomo tanto el Derecho humanitario relativo a la ocupación [en particular, el Reglamento de La Haya sobre las Leyes y costumbres de la Guerra terrestre y el cuarto Convenio de Ginebra; en extenso CHINKIN, Ch., "Laws of Occupation», en Bотна, N. et al. (eds.), Multilateralism and International Law with Western Sáhara as a Case Study, Pretoria, University of South Africa, 2008, pp. 196-221] como también las normas convencionales del Derecho internacional de los derechos humanos, que son eficaces extraterritorialmente en estas situaciones. La interacción de ambos corpus ha sido abordada por el TIJ en casos que presentan analogías con el del Sáhara, como ocurre en el Dictamen sobre el Muro de Palestina o la diferencia entre la RD del Congo y Uganda. En los dos tipos de normas, humanitarias y de derechos humanos, se establecen obligaciones relacionadas con el derecho a un proceso con las debidas garantías que corren a cargo del Estado ocupante, sobre todo, en los supuestos en que la ocupación se prolonga en el tiempo. A consecuencia de todo ello, no comparto la idea expresada por la AN de que si el Sáhara no es legalmente territorio marroquí, no puede aceptarse su jurisdicción como fuero preferente del lugar de comisión del delito. Al contrario, no queda otro remedio que hacerlo, al ser el predeterminado por el ordenamiento internacional; y, ante la probable violación por parte de Marruecos de sus obligaciones, habrá de continuar instándose tanto una respuesta institucional en el plano internacional como la búsqueda de una reparación individual ante los tribunales internos de terceros Estados. Pese a que suene ritual, esto parece más lógico que afirmar que el fuero territorial es el español porque el Sáhara está de iure administrado por España... aunque esto sea una ficción porque hace casi cuarenta años que este Estado no administra nada en dicho territorio. Como se ha señalado «con los derechos humanos el criterio operativo se centra en la noción de jurisdicción —no en la soberanía- y en la idea del control efectivo, sin parar mientes en la legalidad o legitimidad de las acciones de los agentes estatales» (GonZÁlez VEGA, J., op. cit., p. 88). 
10. Volviendo al principio, para terminar. La violación continuada del derecho colectivo a la libre determinación del pueblo del Sáhara Occidental y, en conexión con ésta, la vulneración de los derechos individuales de los saharauis genera una notable frustración, que se ve acrecentada por la debilidad de los mecanismos de respuesta institucional. Frente a ese callejón sin salida aparente puede ser tentador explorar una puerta de escape. En el caso que nos ocupa, aun a pesar de la falta de cooperación judicial marroquí, la activación del principio de jurisdicción universal proporcionaba una vía de acción procesal, ardua pero plausible, para investigar las violaciones de derechos humanos cometidos durante el desalojo del Campamento Dignidad. Tras la reforma operada por la LO 1/2014, sin embargo, dicho procedimiento tendría que haber sido sobreseído. La mutilación de la jurisdicción universal que se ha acometido es tan intensa que no se podría instruir ni tan siquiera un proceso como éste en el que la víctima de un presunto asesinato cometido en un contexto de crímenes contra la humanidad es un ciudadano español (Baby Hamday), puesto que dicho delito sólo sería perseguible cuando el procedimiento estuviese dirigido contra un español, o contra un extranjero que resida habitualmente en España, o contra un extranjero que se encontrara en España y cuya extradición hubiera sido denegada por las autoridades españolas [art. 23.4.a)]. La limitación es tan severa que resulta razonable que surjan dudas tanto sobre la constitucionalidad de la reforma como respecto a si ésta va a provocar el incumplimiento por parte de España de las obligaciones internacionales que le alcanzan. Sin embargo, pese a compartir una valoración crítica de la reforma, pienso que las bases jurídicas para mantener abierto en la AN un proceso como el del Sáhara Occidental haciéndolo pivotar en exclusiva sobre el principio de territorialidad (es decir, afirmando a partir de una ficción jurídica que éste es un territorio español) son insuficientes.

Carlos Teijo García

Universidad de Santiago de Compostela http://dx.doi.org/10.17103/redi.67.1.2015.3a.02

\subsection{Jurisdicción universal: casos Tíbet y Falun Gong}

\section{JURISDICCIÓN UNIVERSAL.-Genocidio.-Torturas.-LO 1/2014, de 13 de marzo.}

Auto de la Audiencia Nacional (Sala de lo Penal, Pleno), de 2 de julio de 2014 (ROJ: ANN 216/2014). Ponente: Julio de Diego López.

Referencia Centrode DocumentaciónJudicial(Id.Cendoj) 28079229912014200002.

Auto de la Audiencia Nacional (Sala de lo Penal, Pleno), de 15 de julio de 2014 (ROJ: ANN 215/2014). Ponente: Nicolás Poveda Peñas.

Referencia Centrode DocumentaciónJudicial(Id.Cendoj) 28079229912014200001.

1. Los dos autos que vamos a comentar a continuación se refieren al sobreseimiento de dos de las ya pocas causas que se encuentran abiertas en la AN en aplicación del principio de jurisdicción universal: el caso Tíbet y el caso Falun Gong. Ambas tienen su origen en querellas por presuntos delitos de genocidio y torturas dirigidas contra antiguos dirigentes chinos. Su admisión a trámite, y sobre todo, las órdenes de busca y captura dictadas contra cinco presuntos responsables del genocidio tibetano, han ocasionado importantes presiones al ejecutivo español por parte de las autoridades chinas. Éstas, sumadas a otros conflictos diplomáticos con autoridades israe- 
líes y estadounidenses por razones similares, han sido las detonantes de la reforma exprés y tajante de la jurisdicción universal a través de la LO 1/2014, de 13 de marzo (BOE núm. 63, de 14 de marzo de 2014, pp. 23026 y ss., véase, sobre esta reforma, entre otros: SÁNCHEz LEgIDo, A., «El fin del modelo español de jurisdicción universal», REEI, 2014, núm. 27).

2. Se trata de una restricción por vía legislativa de la jurisdicción universal que continúa el camino emprendido por la anterior reforma de la LOPJ a través de la LO 1/2009, de 3 de noviembre, que había condicionado ya el ejercicio de esta jurisdicción — configurada hasta ese momento de forma muy amplia- a la concurrencia de alguna de las siguientes tres circunstancias: la presencia de los presuntos responsables en nuestro territorio, la nacionalidad española de la víctima, o la existencia de algún otro vínculo de conexión relevante con España. Y, si esta reforma no había sido suficiente para paralizar muchos de los procedimientos que se estaban tramitando, incluidos los dos a los que estamos haciendo referencia, la introducida por la LO 1/2014 deja a la jurisdicción universal española prácticamente inoperativa. Hecho, que, por otro lado, se encuentra en consonancia con un retroceso casi generalizado de la jurisdicción universal en los ordenamientos jurídicos nacionales europeos que la contemplan (véase un estudio reciente sobre su situación en el Derecho comparado en Robles CARrillo, M., «El principio de jurisdicción universal: estado actual y perspectivas de evolución», REDI, vol. XVI, 2014, núm. 2, pp. 81-111).

3. Entre otras cuestiones, esta reforma ha supuesto la exigencia de mayores vínculos de conexión con España de las causas. Así en relación con los delitos sobre los que versan los dos casos que nos ocupan, se introducen, por una parte, respecto del de genocidio, dos requisitos relacionados con las personas contra las que se dirige el procedimiento: deberán ser españoles o extranjeros que residan habitualmente en España o extranjeros que se encuentren en España y cuya extradición hubiese sido denegada por las autoridades españolas [art. 23.4.a)]. Y, en lo tocante a la tortura, se exige que el procedimiento se dirija contra un español o que la víctima tenga nacionalidad española en el momento de la comisión de los hechos y que la persona a la que se imputa la comisión del delito se encuentre en territorio español [art. 23.4.b)].

4. Asimismo, la disposición transitoria única de esta LO establece que «las causas que en el momento de la entrada en vigor de esta ley se encuentren en tramitación por los delitos a los que se hace referencia en la misma quedarán sobreseídas hasta que no se acredite el cumplimiento de los requisitos establecidos en ella». En consecuencia, en los dos procedimientos que nos ocupan, el Juzgado Central de Instrucción núm. 2 acordó, a instancia del Ministerio Fiscal, la conclusión de los sumarios y su elevación a la Sección 2. ${ }^{\text {a }}$ de la Sala de lo penal de la Audiencia Nacional para que ésta se pronunciase sobre la concurrencia de tales requisitos. Finalmente, las cuestiones fueron remitidas al Pleno de la Sala de lo Penal, que acordó por mayoría su sobreseimiento y archivo. Sin embargo, debe tenerse en cuenta que esta aplicación de la LO 1/2014 no ha sido hasta el momento homogénea por parte de los jueces de instrucción y, en otros casos, como en los relativos al Sáhara, Guantánamo o Couso, sí han continuado dicha instrucción.

5. Si nos centramos en el caso Tíbet, éste tiene su origen en la querella presentada en 2005 por dos asociaciones tibetanas —el Comité de apoyo al Tíbet y la Fundación Casa del Tíbet- y de una víctima de nacionalidad española (véase un recorrido detallado por este procedimiento en el comentario de CHINCHÓN Álvarez, J., REDI, vol. LXVI, 2014, núm. 1, pp. 212-217). Los querellantes alegaron contra el sobreseimiento de la causa derivada de la aplicación de la LO 1/2014 la primacía de las con- 
venciones internacionales en la materia sobre el Derecho interno, que al ser los hechos alegados constitutivos de terrorismo y existir una víctima española no le afecta dicha ley, así como la necesidad de plantear cuestión de inconstitucionalidad. Sin embargo, el auto considera, en primer lugar, que no existe ninguna norma internacional que obligue a los Estados a incorporar el principio de jurisdicción universal y que su límite es una cuestión de política criminal que compete al legislador. Y, en este caso, no concurren los supuestos que el legislador ha configurado en los arts. 23.4.a) y 23.4.b) de la LOPJ: en cuanto a los delitos de genocidio y lesa humanidad, ninguno de los querellados ostenta la nacionalidad española, ni reside en España ni se encuentra en territorio nacional, y, en relación con las torturas, los querellados son nacionales de la República Popular China y no consta tampoco que se encuentren en territorio español. Con base en los mismos argumentos, no se estima necesario, en segundo lugar, el planteamiento de una cuestión de inconstitucionalidad. Y, por último, se afirma que la calificación hecha por los querellantes de los hechos como terrorismo en su escrito de querella no es vinculante, máxime cuando la imputación a los querellados ha sido realizada ya únicamente por delitos de torturas, genocidio y lesa humanidad.

6. Respecto al caso Falun Gong, que tiene su origen en distintas querellas presentadas desde 2003 por la presunta persecución a la que son sometidos en China los practicantes de esa enseñanza religiosa, el auto se limita a considerar que no concurren, igual que en el caso Tíbet, los requisitos impuestos tras la reforma de la LOPJ por la LO 1/2014 para poder continuar con la causa, por lo que, aplicando su disposición transitoria, se procede a su sobreseimiento y archivo.

7. Muy al contrario, los votos particulares a ambas decisiones, suscritos por siete magistrados, coinciden en que la reforma de la LOPJ, operada por la LO 1/2014, es contraria a las exigencias del Derecho internacional en esta materia y en la necesidad de haber planteado una cuestión de inconstitucionalidad ante el TC.

8. Así, en los votos particulares en el asunto Tíbet, los magistrados sostienen, por una parte, que el Derecho internacional convencional sí impone al Estado español la obligación de investigar y perseguir los crímenes de guerra. En concreto, el art. 146 del IV Convenio de Ginebra establece que cada Estado parte «tendrá la obligación de buscar a las personas acusadas de haber cometido u ordenado cometer, una cualquiera de las infracciones graves y deberá hacerla comparecer ante los propios tribunales sea cual fuere su nacionalidad». Se produce así un conflicto normativo con el art. 23.4 de la LOPJ que se debe resolver aplicando la ley que goza de mayor rango normativo: la derivada del tratado internacional. Es decir, se recurre, paradójicamente, al mismo argumento que la AN ha empleado, por ejemplo, en el caso José Couso, para seguir tramitándolo (véase el comentario de SÁNchez Ramos, B., REDI, vol. LXVI, 2014, núm. 2, pp. 181-183). Consideran además, en consonancia con lo establecido por la STC 237/2005, en el caso Guatemala, que la jurisdicción universal de los crímenes de guerra implica la extensión de la jurisdicción del Estado en atención únicamente a la naturaleza del delito, de modo que cuando se exigen vínculos de conexión relacionados con la nacionalidad del perpetrador, la nacionalidad de la víctima o los intereses del Estado, se aplican otros mecanismos de atribución de la jurisdicción. Entienden también que debió haberse planteado la cuestión de inconstitucionalidad de la actual redacción del art. 23 de la LOPJ por vulnerar, por un lado, el derecho fundamental a la igualdad, dado su desigual tratamiento de la personalidad pasiva en las distintas figuras delictivas que contempla y, por otro, el derecho a la tutela judicial efectiva, dado el desentendimiento que se hace de las víctimas si son españolas en los casos de genocidio, crímenes de guerra y contra la humanidad. Además, este derecho a la justi- 
cia estaría reconocido en la legalidad internacional, tanto en instrumentos de derecho estatutario como consuetudinario e, incluso constituiría, en algunas situaciones, ius cogens internacional.

9. En sentido similar se pronuncia el voto particular en el caso Falun Gong, que comienza enmarcando la jurisdicción universal en el desarrollo del Derecho penal internacional como forma de luchar contra la impunidad y del derecho a la reparación de las víctimas de las grandes violaciones de derechos humanos. A continuación, analiza y critica las exigencias del vínculo de conexión para el ejercicio de la jurisdicción universal introducidas por la LO 1/2014, basándose principalmente en la doctrina establecida por el TC en sus Sentencias 237/2005 (caso Guatemala) y 227/2007 (caso Tíbet), concluyendo que conllevan «el total vaciamiento de contenido de la jurisdicción universal (no sólo su limitación)». Por todo ello, estima igualmente que debió haberse planteado cuestión de constitucionalidad contra la LO 1/2014, teniendo en cuenta, además, la vulneración que hace del derecho a la irretroactividad de las leyes restrictivas de derechos humanos.

10. Así las cosas, habrá que estar atentos, para ver si se confirma o no esta drástica restricción de la jurisdicción universal en nuestro sistema jurídico, por un lado, al sentido en el que se pronuncie el TS en relación con el recurso de casación interpuesto contra, al menos, el auto que archiva el caso Tíbet. Y, por otro, a la decisión que adopte el TC en relación con el recurso de inconstitucionalidad contra la LO 1/2014 promovido por diputados del Grupo Parlamentario Socialista en el Congreso, admitido a trámite el 22 de julio de 2014 (BOE núm. 181, de 26 de julio de 2014, p. 59669).

Laura Movilla Pateiro

Universidad de Vigo

http://dx.doi.org/10.17103/redi.67.1.2015.3a.03

\subsection{Competencia extraterritorial de los tribunales penales españoles}

COMPETENCIA EXTRATERRITORIAL DE LOS TRIBUNALES PENALES ESPAÑOLES.-Jurisdicción Universal.-Tráfico de drogas.-Reforma de la Ley Orgánica del Poder judicial.

Auto de la Audiencia Nacional (Pleno de la Sala de lo Penal), de 4 de julio de 2014 (ROJ: AAN 255/2014). Ponente: Juan Francisco Martel Rivero. Voto particular formulado por Fernando Grande Marlaska Gómez, Concepción Espejel Jorquera, Ángel Luis Hurtado Adrián, Nicolás Poveda Peñas y Enrique López López.

\section{Referencia Centrode Documentación Judicial(Id.Cendoj) 28079229912014200038.}

1. En este Auto de 4 de julio el Pleno de la Sala de lo Penal de la Audiencia Nacional se pronuncia sobre un recurso de apelación interpuesto por el Ministerio Fiscal contra el Auto del Juzgado Central de Instrucción núm. 5, de 19 mayo de 2014 (núm. 46/14), que dictaminó el sobreseimiento y archivo del asunto, relativo al tráfico de drogas en el mar, como consecuencia de la interpretación dada por la Sala al art. 23.4 de la LO 1/2014 (BOE núm. 63, de 14 de marzo de 2014, pp. 23026 y ss.) sobre justicia universal (para un estudio detallado de la LO 1/2014 véase RoBLES CARRILLO, M., "El principio de jurisdicción universal: estado actual y perspectivas de evolución», REDI, vol. LXVI, 2014, núm. 2, pp. 81-111).

2. Los hechos que dan lugar a la actuación de la AN son los siguientes: el día 19 de abril de 2014, integrantes del Servicio de Vigilancia Aduanera con base en Almería 
y Málaga proceden al reconocimiento de un buque mercante de bandera de Tanzania, que se encuentra en la zona contigua que rodea al territorio español de la Isla de Alborán, ante la sospecha de que pudiese transportar sustancias estupefacientes. Si bien en una primera inspección preliminar, realizada con el permiso del capitán, no se detectó la existencia de estupefacientes a bordo del buque, sin embargo, en un segundo examen más exhaustivo, realizado en el puerto de Almería, fueron descubiertos, en un compartimiento de la bodega, 639 fardos conteniendo hachís con un peso aproximado de 16 toneladas. Consecuentemente, los siete tripulantes — de nacionalidad siria— fueron detenidos. Posteriormente, el Juzgado Central de Instrucción núm. 5, por Auto de 19 de mayo, acuerda el sobreseimiento y archivo de la causa, "con la consiguiente puesta en libertad de los siete tripulantes de la embarcación incautada, ante la falta de jurisdicción - a juicio de la Sala— de los órganos judiciales españoles para investigar, y enjuiciar posteriormente, los hechos contenidos en el atestado que dio origen a la incoación del procedimiento» (FJ 1 del Auto de 14 de julio). Y ello porque la Sala considera que el precepto aplicable es el art. 23.4.i) de la LO 1/2014 que establece que «también conocerá la jurisdicción española de los delitos que hayan sido cometidos fuera del territorio nacional, siempre que los criminalmente responsables fueren españoles o extranjeros que hubieran adquirido la nacionalidad española con posterioridad a la comisión del hecho y concurrieren los siguientes requisitos: [...] i) tráfico ilegal de drogas tóxicas, estupefacientes o sustancias psicotrópicas, siempre que: $1 .^{\circ}$ el procedimiento se dirija contra un español; o $2 .^{\circ}$ cuando se trate de la realización de actos de ejecución de uno de estos delitos o de constitución de un grupo u organización criminal con miras a su comisión en territorio español», circunstancias que no concurren en los acusados (sobre este particular — tráfico de drogas y jurisdicción universal- véase comentario de GARCía ANDRADE, P., REDI, vol. LXVI, 2014, núm. 2, pp. 214-221, y Segura Serrano, A, «Vicisitudes de la jurisdicción universal tras la reforma de la Ley Orgánica del Poder Judicial de 2014», REDI, vol. LXVI, 2014, núm. 2, pp. 316-319).

3. Sin embargo, el Ministerio Fiscal mantiene, en su recurso de apelación, que la norma aplicable es el art. 23.4.d) de la LO 1/2014 por lo que, consecuentemente, los tribunales españoles tienen competencia para seguir conociendo de los hechos, a pesar de la entrada en vigor de la citada LO 1/2014. Pero además, y ahí radica a nuestro entender el interés de este auto - junto con el Voto Particular que lo acompaña y que analizaremos posteriormente-, el Ministerio Fiscal realiza una aproximación al espacio en el que se producen los hechos, la zona contigua, a las competencias del Estado ribereño sobre ese espacio, así como a las Convenciones que, a su entender, son aplicables al caso: la Convención de Naciones Unidas sobre Derecho del Mar de 1982 y la Convención de Naciones Unidas contra el tráfico ilícito de estupefacientes y sustancias psicotrópicas de 1988. Y la interrelación de todos estos «elementos» le lleva a sostener — posición que compartimos- la competencia de nuestros tribunales como ya hemos apuntado. Realizaremos, por tanto, un recorrido por estos «elementos».

4. En cuanto al espacio en el que se producen los hechos, la zona contigua, el Ministerio Fiscal recuerda que si bien no estamos ante un espacio sobre el que el ribereño ejerza sus derechos soberanos, sin embargo, ello no quiere decir que no disfrute de competencias en esta zona, sino que, como es sabido, le corresponden ciertas competencias funcionales. En este sentido, el art. 33 de la Convención de Naciones Unidas sobre Derecho del Mar establece que «el Estado ribereño podrá tomar las medias de fiscalización pertinentes para: 1) prevenir las infracciones a sus leyes y reglamentos aduaneros, fiscales, de inmigración o sanitarios que pudieran cometerse en su territorio o mar territorial; 2) sancionar las infracciones de estas leyes y reglamentos co- 
metidas en su territorio o mar territorial». Consecuentemente con esta disposición, el Ministerio Fiscal entiende que es de aplicación la LO 6/2011, de 30 de junio, por la que se modifica la LO 12/1995, de 12 de diciembre, de Represión del Contrabando (BOE núm. 156, de 1 de julio de 2014), cuyo art. 2.1.g) establece que "cometen delito de contrabando, siempre que el valor de los bienes, mercancías, géneros o efectos sea igual o superior a 150.000 euros, los que realicen alguno de los siguientes hechos: [...] g) alijen o transborden de un buque clandestinamente cualquier clase de mercancías, géneros o efectos dentro de las aguas interiores o del mar territorial español o zona contigua, o en las circunstancias previstas por el art. 111 de la Convención de Naciones Unidas sobre el Derecho del Mar, hecha en Montego Bay, Jamaica, el 10 de diciembre de 1982». Consecuentemente, el Ministerio Fiscal sostiene que «la zona contigua permite al Estado ribereño tomar las medidas enunciadas, por lo que al no formar parte del territorio nacional, pero estar prevista en nuestra legislación interna la comisión de delitos perseguibles en España, ha de considerarse que nos encontramos ante un delito cometido fuera del territorio nacional, previsto en el art. 23.4.d) de la LOPJ, en que la competencia para su instrucción y enjuiciamiento corresponde a los órganos de la Audiencia Nacional, en virtud de los arts. 65.1.e) y 88 de la referida Ley» (FJ 1).

5. En cuanto a la competencia de los tribunales españoles para seguir conociendo del asunto, el Ministerio Fiscal entiende que a la luz de la Convención de Naciones Unidas sobre Derecho del Mar y de la Convención de Naciones Unidas contra el tráfico ilícito de estupefacientes y sustancias psicotrópicas —especialmente arts. 4 y 17- la disposición a aplicar es el art. 23.4.d) de la LO 1/2014 y no el art. 23.4.i) como dictaminó la Sala dado que «la persecución del tráfico de drogas se recoge en las normas de los apartados d) e i) del art. 23.4 de la LOPJ, pero desde perspectivas diferentes». Así, en el apartado d), de aplicación preferente por ser norma especial, se tiene en cuenta el espacio marino en el que se comete el delito, en tanto que el apartado i) se circunscribe al tráfico de drogas cometido fuera del territorio nacional, pero en el lugar que no constituya espacio marino. Por lo que concluye que «de la mencionada normativa se deduce la competencia de las autoridades judiciales españolas para investigar y enjuiciar los hechos de autos, debiendo revocarse el auto recurrido y ordenar la continuación del procedimiento» (FJ 1). Tesis, la de la consideración del art. 23.4.d) como «norma especial» respecto al art. 23.4.i), que ha mantenido también el Tribunal Supremo en diversos pronunciamientos recientes sobre esta materia.

6. Por el contrario, la Sala mantiene que la disposición aplicable que le lleva a dictaminar el sobreseimiento es el art. 23.4.i) de la LO 1/2014. Para la Sala, de una lectura conjunta de la Convención de Naciones Unidas sobre Derecho del Mar y de la Convención de Naciones Unidas contra el tráfico ilícito de estupefacientes y sustancias psicotrópicas no cabe más que deducir que «España no asume ninguna competencia por el hecho de adoptar las medidas previstas en el artículo 17.4 de la Convención de Naciones Unidas sobre tráfico ilícito de drogas de 1988. Únicamente será competente cuando se den los requisitos a los que se refiere el vigente artículo 23.4.i) de la LOPJ. Si no se dan esos requisitos, la adopción de dichas medidas no traspasa el umbral de la cooperación o asistencia a la que España y las Partes firmantes de la Convención quedan obligadas para eliminar el tráfico ilícito por mar, sin ser, por tanto, criterio de atribución de jurisdicción. La razón es sencilla: el artículo 17 de la Convención no establece la jurisdicción de los Tribunales de los Estados que auxilien o colaboren en la eliminación del tráfico ilícito. Las declaraciones programáticas establecidas en las tres Convenciones mencionadas requieren una materialización legislativa interna que en España actualmente se produce en el artículo 23.4.i) de la LOPJ» (FJ 2). Es más, la Sala entiende que, a tenor del vigente art. 23.4.d) de la LO 1/2014 «será competente la 
jurisdicción española para conocer de los hechos cometidos por españoles o extranjeros fuera del territorio nacional susceptibles de tipificarse, según la ley española, como delito de tráfico ilegal de drogas, estupefacientes o sustancias psicotrópicas de 1988. España como Estado parte podrá adoptar las medidas que sean necesarias para declararse competente respecto del tráfico ilícito. Y esta declaración de competencia viene determinada en la reforma del artículo 23.4.i) de la LO 1/2014».

7. Este auto viene acompañado de un Voto Particular firmado por los Magistrados Grande Marlaska, Espejel Jorquera, Hurtado Adrián, Poveda Peñas y López López, quienes amparándose en las disposiciones de Derecho interno, de Derecho internacional y de la jurisprudencia del Tribunal Supremo, entiende que cabe otra interpretación de la LO 1/2014 que les lleva a considerar que nuestros tribunales sí son competentes para seguir conociendo del asunto. En este sentido cabe apuntar, en primer lugar, que en la discusión sobre la disposición aplicable para determinar la jurisdicción de nuestros tribunales [art. 23.4.d) o 23.4.i) de la LO 1/2014] en este Voto Particular se apunta que, a su juicio - interpretación que nosotros compartimos - «a diferencia de lo que ocurre respecto de los demás delitos contemplados en los restantes apartados del citado art. 23.4 de la LOPJ, e incluso del mismo tipo de delitos cometidos en espacios terrestres, el legislador no ha introducido restricción alguna al ejercicio de la jurisdicción por los órganos judiciales españoles cuando los delitos expresados son cometidos en espacios marinos, dejando a salvo, obviamente, los límites que puedan derivar de los tratados ratificados por España u otros instrumentos internacionales vinculantes para España». En segundo lugar, y en relación con el Derecho internacional, los magistrados consideran que el tráfico de estupefacientes es un delito internacional grave y que toda la Comunidad internacional tiene interés en su persecución (tal y como se deduce de diversas disposiciones de la Convención de Naciones Unidas sobre Derecho del Mar y de la Convención sobre tráfico de drogas). Es más, de especial relevancia es el art. 4 de la Convención sobre tráfico de drogas al obligar a cada Estado parte a adoptar las medidas necesarias para declararse competente respecto de estos delitos cuando el presunto delincuente se encuentre en su territorio y dicha Parte no la extradite a otra, con la finalidad de evitar la impunidad de los presuntos culpables. Y, por último, en cuanto a la Jurisprudencia del Tribunal Supremo, los magistrados traen a colación diversas sentencias relativas a delitos de tráfico ilícito de migrantes en alta mar a bordo de embarcaciones sin pabellón donde se declaraba la competencia de la jurisdicción española, interpretación que, a su juicio, es trasladable al presente asunto.

8. Lo cierto es que la aplicación de la LO 1/2014 ha causado un auténtico revuelo mediático por las consecuencias prácticas de su aplicación e interpretación —no siempre adecuadas, a nuestro juicio- que han llevado, como en el caso que nos ocupa, a la puesta en libertad de siete presuntos culpables de un delito de tráfico de drogas.

$$
\begin{array}{r}
\text { Belén SÁNchez Ramos } \\
\text { Universidad de Vigo } \\
\text { http://dx.doi.org/10.17103/redi.67.1.2015.3a.04 }
\end{array}
$$

\subsection{Jurisdicción universal: delitos contra la salud pública}

JURISDICCIÓN UNIVERSAL.-Delitos contra la salud pública.-Tráfico de drogas.-Competencia de la jurisdicción española._LOPJ.-Redacción de la LO 1/2014.-Extraterritorialidad.-Motivos: infracción de ley; infracción de preceptos constitucionales. 
Sentencia del Tribunal Supremo (Sala de lo Penal) de 24 de julio de 2014 (ROJ: STS 3082/2014). Ponente: Juan Artemio Sánchez Melgar.

Referencia CentrodeDocumentaciónJudicial(Id.Cendoj) 28079129912014100001.

Sentencia del Tribunal Supremo (Sala de lo Penal) de 24 de julio de 2014 (ROJ: STS 3089/2014). Ponente: Juan Artemio Sánchez Melgar.

Referencia Centrode DocumentaciónJudicial(Id.Cendoj) 28079120012014100549.

Auto del Tribunal Supremo (Sala de lo Penal) de 18 de septiembre de 2014 (ROJ: ATS 7517/2014). Ponente: José Manuel Maza Martín.

Referencia Centrode DocumentaciónJudicial(Id.Cendoj) 28079120012014201903.

1. Las dos sentencias y el auto analizados versan sobre la interpretación de los nuevos preceptos sobre la jurisdicción universal en el ordenamiento jurídico español tras las modificaciones aportadas por la nueva Ley Orgánica en la materia, 1/2014, de 13 de marzo, que viene a modificar la versión precedente de la LOPJ 6/1985, en 2009, que había hecho lo propio con la redacción inicial de esta Ley. Si la redacción de 1985 se caracterizaba por una jurisdicción universal ilimitada o absoluta en ciertos delitos de relevancia internacional, en 2009 se habían aportado modificaciones restrictivas tendientes a probar un vínculo relevante entre las causas enjuiciadas y España. Sin embargo, en 2014, la nueva versión de la Ley tiende a acomodarse a lo dispuesto en los tratados internacionales de los que España es parte y a ellos remite en cuanto a la posibilidad de enjuiciar delitos por medio de la jurisdicción universal por parte de los tribunales españoles. Esta jurisdicción es la posibilidad de declararse competente, por estos tribunales, para enjuiciar casos que carezcan de vínculo de conexión territorial ni de personalidad activa (autor) o pasiva (víctima), en caso de que los hechos se produzcan en el extranjero e incumban a individuos de nacionalidad no española.

2. La primera sentencia (STS 3082/2014) objeto de este comentario contiene la interpretación sustancial que es retomada en los dos otros textos y constituirá por ello el objeto esencial de mi análisis. Las diferencias con la segunda sentencia del mismo día son mínimas y conciernen por lo esencial a los fundamentos factuales, como, por ejemplo, que el barco no tiene pabellón en la segunda sentencia, y no los fundamentos de Derecho, que remiten al primer caso. En cuanto al auto, posterior, basta decir que es conforme y consecuente con la interpretación realizada en la primera sentencia, de lo que se puede extraer que la doctrina del Tribunal Supremo, que esta Sentencia de 24 de julio establece, es fundacional y destinada a interpretar la Ley Orgánica del Poder Judicial en casos similares de jurisdicción universal y a establecer esta última cuando el objeto del procedimiento sea un abordaje en aguas internacionales en supuestos de tráfico de drogas.

3. En efecto, se trata del abordaje por una patrulla española y con consentimiento del Estado de pabellón, de un navío con bandera de Sierra Leona y tripulantes de nacionalidad siria en aguas internacionales por tráfico de drogas con incautación de una cantidad importante de hachís, y del sobreseimiento inicial de la causa por el Juzgado Central de Instrucción por falta de jurisdicción, confirmado por la Audiencia Nacional. El Ministerio Fiscal, con criterio diferente, consideró que existía esta jurisdicción con arreglo a la Ley Orgánica del Poder Judicial y a la Con- 
vención de Naciones Unidas contra el tráfico ilícito de estupefacientes y sustancias psicotrópicas de 1988, e interpuso recurso de casación contra el auto del Pleno de la Sala de lo Penal de la Audiencia Nacional por infracción de la Ley Orgánica del Poder Judicial en su nueva versión tras la LO 1/2014. Este auto había desestimado el recurso de apelación del Ministerio Fiscal contra el auto del Juzgado Central de Instrucción que declaraba la falta de jurisdicción de los tribunales españoles para tratar el caso. Para el tratamiento de este recurso de casación se estima competente el Tribunal Supremo.

4. Conviene por tanto, como lo hacen los diferentes órganos judiciales, analizar las disposiciones tanto de la Ley Orgánica del Poder Judicial como de la Convención de Naciones Unidas de 1988. El aspecto esencial de estas sentencias es la interpretación que hacen los tribunales españoles de unos preceptos legales cuanto menos ambiguos, por no decir contradictorios o poco resolutivos, que intentando precisar la jurisdicción universal aplicable en España, tratan igualmente de no violar las normas internacionales en la materia, conduciendo así a una regulación que puede ser calificada de equilibrio inestable y que otorga un papel esencial a los tribunales en su aplicación, como lo muestran estos casos.

5. Es necesario recordar que la Ley Orgánica del Poder Judicial dispone, en la redacción actualmente en vigor de su art. 23.4, lo siguiente:

«Igualmente, será competente la jurisdicción española para conocer de los hechos cometidos por españoles o extranjeros fuera del territorio nacional susceptibles de tipificarse, según la ley española, como alguno de los siguientes delitos cuando se cumplan las condiciones expresadas:

[...] d) Delitos de piratería, terrorismo, tráfico ilegal de drogas tóxicas, estupefacientes o sustancias psicotrópicas, trata de seres humanos, contra los derechos de los ciudadanos extranjeros y delitos contra la seguridad de la navegación marítima que se cometan en los espacios marinos, en los supuestos previstos en los tratados ratificados por España o en actos normativos de una Organización Internacional de la que España sea parte.

[...] i) Tráfico ilegal de drogas tóxicas, estupefacientes o sustancias psicotrópicas, siempre que:

$1 .^{\circ}$ el procedimiento se dirija contra un español; o, $2 .^{\circ}$ cuando se trate de la realización de actos de ejecución de uno de estos delitos o de constitución de un grupo u organización criminal con miras a su comisión en territorio español.

[...] p) Cualquier otro delito cuya persecución se imponga con carácter obligatorio por un Tratado vigente para España o por otros actos normativos de una Organización Internacional de la que España sea miembro, en los supuestos y condiciones que se determine en los mismos».

6. Las letras d) e i) establecen condiciones de aplicación distintas, siendo más restrictivas las de la letra $i$ ). Pero como lo afirma el Tribunal Supremo, y contrariamente a lo que establece el Juzgado de Instrucción en su resolución, no se trata de disposiciones fundamentalmente similares, repetidas o complementarias sino excluyentes y autónomas, se aplica la una o la otra, y si es de aplicación la letra $d$ ) no es necesario incorporar los criterios o requisitos de la letra $i$ ), más restrictivos. En efecto, la letra $d$ ) es aquí de aplicación ya que el supuesto especial de abordaje acaece en aguas internacionales, citadas por la Ley Orgánica del Poder Judicial como «espacios marinos». Ello excluye la aplicación de los requisitos de la letra $i$ ). Lo que implica que para tener o no jurisdicción, los Tribunales han de remitirse a los tratados internacionales en la materia, véase la convención de 1988, y no será necesario que el procedimiento se dirija contra un español ni que se presumiera que el delito de tráfico de drogas fuera a cometerse en el territorio español. 
7. Por ello, como lo recuerda el Tribunal Supremo, es necesario citar el art. 4.1.b) de la Convención de 1988, tratado aplicable y que contiene los supuestos aplicables en la materia, y según el que cada una de las Partes, y entre ellas España, "podrá adoptar las medidas que sean necesarias para declararse competente respecto de los delitos que haya tipificado de conformidad con el párr. 1 del artículo 3» (transporte de sustancias estupefacientes):

[...] ii) Cuando el delito se cometa a bordo de una nave para cuya incautación dicha Parte haya recibido previamente autorización [es el caso] con arreglo a lo previsto en el artículo 17, siempre que esa competencia se ejerza únicamente sobre la base de los acuerdos o arreglos a que se hace referencia en los párrafos 4 y 9 de dicho artículo».

Deben subrayarse los términos "podrá adoptar». A esta disposición se añade una norma de cierre, en el apartado 3 de dicho art. 4, que dispone que «[1]a presente Convención no excluye el ejercicio de las competencias penales establecidas por una Parte de conformidad con su derecho interno». Es claramente una disposición permisiva pero no impositiva.

8. Dicho esto, y teniendo en cuenta que el motivo principal por el que el Juzgado de Instrucción consideró que no tenía jurisdicción para conocer del caso es la aplicación complementaria de los requisitos de la letra $i$ ) del art. 23.4, que no se reunirían aquí a su juicio, y que en todo caso no es procedente por las razones indicadas por el Tribunal Supremo que se limita a la aplicación de la letra d), el Tribunal Supremo se plantea si cabe atribuir jurisdicción a los tribunales españoles con base únicamente a lo dispuesto por la letra $d$ ) y el tratado internacional correspondiente al que reenvía sin nombrarlo, es decir, la Convención de 1988.

9. Es aquí donde, en mi opinión, la interpretación que hace el Tribunal Supremo de la Ley Orgánica del Poder Judicial es excesivamente voluntarista, dándole un significado que si no puede calificarse contra legem, sí se aleja claramente de una interpretación literal, lo que puede explicar la referencia que hace el Tribunal a la exposición de motivos para darle una cierta base teleológica, con arreglo a las finalidades de la norma. En efecto, el Juzgado de Instrucción comete un error al aplicar la letra $i$ ) de manera complementaria, pero afirmaba en su resolución que sólo serán competentes los tribunales españoles cuando exista un tratado internacional que atribuya competencia a España, lo cual es ciertamente conforme con lo dispuesto por la letra $d)$.

10. Sin embargo, en mi opinión, contrariamente a lo afirmado por el Tribunal Supremo en estas sentencias, el tratado de 1988 no atribuye competencia a los tribunales de un Estado parte: esta convención atribuye la facultad de prever esta competencia en el Derecho interno y no atribuye directamente la competencia. España "podrá adoptar las medidas que sean necesarias para declararse competente». Debe diferenciarse la posibilidad que otorga aquí el Derecho internacional a los Estados para declarar la jurisdicción de sus tribunales en sus normas internas, y la previsión explícita de esta jurisdicción como obligatoria, que esta Convención no realiza de ninguna manera.

11. Así, el Tribunal Supremo concluye que «en definitiva, en los casos de delitos de tráfico ilegal de drogas tóxicas, estupefacientes y sustancias psicotrópicas, cometidos en medios marinos, el apartado d) del art. 23.4 de la LOPJ confiere jurisdicción a las autoridades españolas para el abordaje, inspección, incautación de sustancias y detención de los tripulantes de cualquier embarcación que enarbole el pabellón de otro Estado, siempre que obtenga la autorización del Estado de abanderamiento del barco». El Tribunal se basa en la Convención de 1988. 
12. Parece el Tribunal Supremo obviar o desconocer que en los tratados internacionales que prevén la jurisdicción universal existen dos tipos de disposiciones: un primer tipo que, como en la Convención de 1988, reenvía a lo dispuesto en el Derecho interno ("podrán adoptarse las medidas») y no impone la existencia de esta jurisdicción universal, sino que la deja como una opción para cada Estado parte, y otro más firme que impone a los Estados partes la toma de medidas adecuadas para enjuiciar estos casos. En este último grupo se encuentra por ejemplo la Convención contra la tortura de 1984 (art. 5.2, «Todo Estado parte tomará asimismo las medidas necesarias para establecer su jurisdicción sobre estos delitos»), o los cuatro Convenios de Ginebra de 1949, con su artículo común 49, 50, 129 y 246, que hablan de «obligación» de los Estados parte («Cada una de las Partes Contratantes tendrá la obligación de buscar a las personas acusadas de haber cometido, u ordenado cometer, una cualquiera de las infracciones graves, y deberá hacerlas comparecer ante los propios tribunales, sea cual fuere su nacionalidad»). En otros términos, de la misma manera que la redacción nacional de las normas de jurisdicción universal oscila entre una versión «absoluta» (LOPJ, versión de 1985) o «limitada» (LOPJ, versiones de 2009 y de 2014), las normas internacionales hacen lo propio, otorgando a los Estados la simple facultad de establecer esta jurisdicción (como la Convención de 1988 aquí tratada) o la obligación de hacerlo (como la Convención de 1984 o los Convenios de 1949). En estos últimos casos, la formulación de la letra d) del art. 23.4 tendría una aplicación más sencilla.

13. Por ello, se trata de un supuesto original y particularmente interesante en el que normas nacionales españolas de jurisdicción universal limitada reenvían a normas convencionales que a su vez hacen depender el ejercicio efectivo de la jurisdicción de la existencia de normas internas: ninguna de ellas da jurisdicción a los tribunales españoles, sin por ello descartarla. Deducir de ello la existencia de una jurisdicción universal en la materia como lo hace el Tribunal Supremo parece un razonamiento discutible: esta competencia puede existir, pero debe ser prevista por las normas correspondientes, en este caso, la LOPJ, que no lo hace, sino que la contempla como una opción dependiente de los tratados. La suma de dos opciones o facultades en normativas de ámbito distinto no impone efectivamente ninguna jurisdicción, sino que permite constatar que dicha opción no ha sido elegida por el Estado.

14. Buscando la conformidad con las normas internacionales, la redacción actual, de 2014, de la LOPJ, parece por tanto sufrir una cierta indefinición y atribuir a los jueces, aquí el Tribunal Supremo, la facultad de afirmar o no una jurisdicción universal cuyas condiciones de establecimiento deberían estar claramente reguladas por ley. Cierto que la interpretación voluntarista del Tribunal Supremo en estas sentencias va en el mismo sentido que los objetivos de las normas internacionales de justicia universal, la lucha contra la impunidad por medio del establecimiento de tal jurisdicción, lo que es de destacar y constituye una evolución con respecto a 2009. Cierto también que la consecución de dicho objetivo no permite paliar ni justificar las imperfecciones técnicas del legislador, que por no volver a una jurisdicción universal real aunque limitada a ciertos supuestos específicos, ya rechazada en 2009, incurre en una imprecisión jurídicamente criticable y deja en manos de los jueces lo que debería ser lo decidido en el Parlamento. La prudencia excesiva de una ley imprecisa y con lagunas no puede escudarse en la audacia futura de los tribunales en su aplicación, siempre incierta y potencialmente variable. 


\title{
3.5. La denegación del derecho de asilo y de la protección subsidiaria por motivos de seguridad nacional
} DERECHO DE ASILO.-Motivo de denegación de asilo.-Ceguridad nacional.-
Art. 9 de la Ley del Asilo.

\author{
Sentencia de la Audiencia Nacional (Sala de lo Contencioso, Sección 2. ${ }^{a}$ ), de 17 \\ de julio de 2014 (ROJ: SAN 3633/2014). Ponente: Jesús N. García Paredes.
}

\section{ReferenciaCentrode Documentación Judicial(Id.Cendoj) 28079230022014100397.}

1. La sentencia de la AN que comentamos estima parcialmente un recurso contencioso-administrativo interpuesto por un nacional kazajo contra una resolución del subsecretario del Interior, de 11 de junio de 2013, en la que se le denegó el derecho de asilo y la protección subsidiaria. La resolución del subsecretario de Interior mantenía que su presencia en España, según un informe del Centro Nacional de Inteligencia (CNI), podría suponer un riesgo para la seguridad nacional y, por tanto, denegó la protección internacional en virtud del art. 9.a) de la Ley de Asilo (FJ 3).

2. Al margen de que resulta una situación excepcional, dentro de la extraordinariamente amplia y casuística jurisprudencia sobre el asilo, en diversas ocasiones los tribunales españoles han aplicado el motivo basado en la seguridad nacional, tanto como causa para denegar la concesión del estatuto de refugiado (véase STS de 18 de diciembre de 2009, Sala de lo Contencioso, Sección 5. a, STS de 30 de diciembre de 2009, Sala de lo Contencioso, Sección 5. ${ }^{\mathrm{a}}$, REDI, vol. LXII, 2010, núm. 2), como para su revocación una vez concedido (así, en la SAN de 3 de octubre de 2013, Sala de lo Contencioso, Sección 2. ${ }^{\text {, }}$ con nota de Arrufar CÁrdava, A., REDI, vol. LXI, 2009, núm. 2, pp. 464-467; asimismo, GARRIDO MuÑOZ, A., «Crónica de aplicación jurisprudencial del Derecho internacional público», REEI, 2013, núm. 23; STS de 2 de octubre de 2008, Sala de lo contencioso, Sección 5. a , REDI, vol. LXI, 2009, núm. 2, pp. 464467). La presente decisión aplica los criterios que se han definido en este ámbito, que descansan esencialmente en acreditar la existencia de «razones fundadas» para la seguridad interna. El presente asunto tiene el mérito de remitirse con detalle a la normativa internacional y europea, así como a la jurisprudencia del TJUE, a diferencia de otras decisiones en las cuales el elemento internacional estaba ausente en su argumentación.

3. En última instancia, la aportación fundamental de este pronunciamiento se refiere a la clarificación de las exigencias impuestas en la aplicación de la cláusula vinculada con la "seguridad nacional», pero también se encuentran en esta decisión una serie de motivos vinculados con defectos de forma en el desarrollo del procedimiento que merecen comentarse. De forma destacada, la AN se pronunció sobre el trámite de audiencia del ACNUR antes de adoptarse la resolución sobre la solicitud. El art. 35 de la Ley del Asilo prevé que el representante del ACNUR será convocado a las sesiones de la Comisión Interministerial de Asilo y Refugio, mientras que en su apartado tercero indica que si la propuesta de resolución de la Oficina de Asilo y Refugio fuese desfavorable se dará un plazo de diez días al ACNUR para que, en su caso, informe. En la decisión de la Sala se señala que se convocó al ACNUR en la tarde del viernes 24 de mayo de 2013 para acudir a la reunión del CIAR del lunes 27 de mayo de 2013 y que, debido a la necesidad de estudiar el expediente, el ACNUR solicitó una ampliación del plazo antes de presentar su informe, petición que no se atendió. La AN afirmó que se trataría «de un cumplimiento defectuoso, pero no del incumplimiento de dicho 
trámite, por lo que no se han infringido normas procedimentales» (FJ 4). En la jurisprudencia se ha señalado que la no presentación del informe por parte del ACNUR, una vez que se ha enviado la petición, no es causa de la anulación por motivos formales, por cuanto el aspecto esencial es el trámite de audiencia y no la respuesta. No obstante, la tramitación de la propuesta se considera una «infracción palmaria» de la Ley del asilo, según se argumenta con detalle en la segunda de las razones expuesta en el voto particular de dos de los Magistrados de la Sala, Jesús Cudero Blás y Francisco José Navarro Sanchís.

4. De igual forma, a pesar de que el interesado no conoció el informe de CNI antes de redactar la propuesta de resolución, el Tribunal consideró que esta falta de audiencia del interesado, que no le permitió hacer alegaciones en ese momento, se suplió durante el desarrollo del expediente y no se produjo indefensión (FJ 5). Por último, dentro de los motivos de forma, tampoco se consideró por la Sala que se hubiera infringido el art. 26 de la Ley del asilo, que prohíbe dirigirse directamente a las autoridades nacionales a la hora de recabar datos sobre la veracidad o no de los hechos y circunstancias invocadas por el solicitante, por cuanto no constaba en el Informe del CNI esta circunstancia (FJ 7); como apoyo a este pronunciamiento, el Tribunal afirma que también se refiere a ese principio de discreción procedimental, el art. 30 de la Directiva 2013/32, si bien esta Directiva refundida sobre los procedimientos de protección internacional no entrará en vigor hasta 2015 y es el art. 22 de la Directiva 2005/85/CE, de 1 de diciembre, el que regula en el mismo sentido esta materia.

5. Después de rechazar los motivos basados en defectos procedimentales, el Tribunal entra a analizar el fondo del asunto, que se centraba en el análisis de la alegada inexistencia de peligro para la seguridad nacional. A este respecto, la Sala se muestra relativamente crítica con la aplicación de este concepto, y afirma que «con este concepto jurídico indeterminado se concede a las autoridades españolas un amplio margen de discrecionalidad a la hora de rechazar la protección internacional solicitada sobre la base de razones no precisas ni precisadas de orden público o seguridad pública, y que configuran el concepto de "seguridad nacional", todo ello, en el marco de esa creciente preocupación internacional por los temas de seguridad, que está incidiendo en la interpretación y ámbito del concepto de refugiado» (FJ 9).

6. En su decisión la AN realiza un esfuerzo por integrar la cláusula relativa al «peligro para la seguridad interior del Estado» dentro de las cláusulas de exclusión, si bien reconoce que la Convención de Ginebra las sitúa fuera de este ámbito. En el art. 3.2 de la antigua Ley 5/1984, reguladora del Derecho de Asilo y del Reconocimiento de la Condición de Refugiado aparecía esta identificación entre ambos supuestos, a través de una remisión a la Convención sobre el Estatuto de los Refugiados, en la medida en que establecía que «no se concederá asilo a quienes se encuentren comprendidos en alguno de los supuestos previstos en los arts. 1.f) y 33.2 de la Convención de Ginebra de 1995». En cierta manera, aunque constatando su diversa regulación internacional, el pronunciamiento de la AN señala que el peligro para la seguridad interior del Estado se «trata de una "causa de exclusión", inspirada en el art. 1 (D, E y F) de la Convención de Ginebra sobre el Estatuto de los Refugiados de 1951, tal como fue modificada por el Protocolo de Nueva York de 31 de enero de 1967, pero que en nuestro ordenamiento jurídico, regulador de la protección internacional, se rubrica como "causa de denegación", como se contempla en el citado art. 9, de la Ley 12/2009, o, como "causa de revocación", prevista en el art. 44.1.c), de la citada ley; y decimos inspirada porque las amenazas a la seguridad y el peli- 
gro para la comunidad no aparecen como causas de exclusión en el citado art. 1.F, sino como excepciones a la prohibición de expulsión y devolución de un refugiado (art. 33.2)» (FJ 9).

7. En el pronunciamiento se apunta, además, aunque de una forma no excesivamente clara, que la separación entre las cláusulas de exclusión (art. 8) y de denegación (art. 9) en la Ley 12/2009 del Asilo, tiene su origen en las normas adoptadas dentro de la UE; señalando en particular los arts. 21.2.a) y 12 de la Directiva 2004/83/CE. Como se sabe, la Ley del Derecho de asilo adaptó el ordenamiento interno, por lo que afecta a las disposiciones aplicadas en este asunto, a la Directiva 2004/83/CE del Consejo, de 29 de abril (DO L 304/12, de 30 de septiembre de 2004). La adopción del paquete legislativo relativo al Sistema Común Europeo de Asilo, completado finalmente en el año 2013, implica la refundición de la Directiva 2004/83/CE en la Directiva 2011/95/ UE, de 13 de diciembre (DO L 337/9, de 20 de diciembre de 2011), que entró en vigor en enero de 2012, a los veinte días de su publicación en el Diario Oficial, si bien en el ámbito al que se refiere la decisión de la AN no se han incorporado modificaciones. De forma constante, el ACNUR advierte que la cláusula de seguridad nacional debe interpretarse de forma restrictiva, al incluirse dentro de una excepción al principio general previsto en el art. 31 y que no puede considerarse una nueva cláusula de excepción, en la medida en que no excluiría su condición de refugiado, sin que pudieran ampliarse las cláusulas de excepción enumeradas de forma taxativa en la Convención [sobre las discusiones y el compromiso alcanzado entre los Estados miembros, que explican esta regulación véase el comentario a la Directiva 2004/83 en HaIlBRonNER, K. (ed.), EU immigration and asylum law. Commentary on EU regulations and directives, Munich, C. H. Beck Verlag, 2010, pp. 985 y ss., en particular, pp. 1104 y ss.; por su parte, aludiendo a que da la impresión de que se trata de un "formalismo terminológico», véase SÁNCHEZ LEgIDO, A., "Entre la obsesión por la seguridad y la lucha contra la inmigración irregular: a propósito de la nueva Ley de asilo», REEI, 2009, núm. 18, p. 12].

8. Asimismo, el Tribunal señala que en el momento de aplicar esta «cláusula de exclusión», contemplada como "causa de denegación», se han de extremar los razonamientos y motivos sobre los que sustenta el «peligro para la seguridad nacional». En función de estas exigencias, la AN se remite a los pronunciamientos previos en los que se ha construido una doctrina jurisprudencial rigurosa, incluyendo diversas Sentencias del TC en las que se regulan las condiciones de limitación a los derechos fundamentales (FJ 10). En términos gráficos, la AN afirma la necesidad de razones sólidas para que prevalezca el «temor» del Estado sobre los motivos que invoca el solicitante, esto es, motivaciones convincentes y argumentadas, que están apoyadas en un sustento fáctico del que se extraigan consecuencias lógicas. Por otra parte, se requiere que la peligrosidad suponga un riesgo para el país en que se encuentra, no siendo suficiente un riesgo potencial o abstracto, sino concreto y determinado derivado de la presencia en el territorio.

9. Por otra parte, el pronunciamiento de la AN se refiere, como elemento complementario en su interpretación, a la decisión del TJUE de 9 de noviembre de 2010, en los asuntos acumulados C-57/09 y C-101/09, bajo el epígrafe «Jurisprudencia del Tribunal de Justicia Europeo». El pronunciamiento del TJUE serviría, según destaca en el FJ 11 para «apoyar los argumentos sobre la necesidad de que, por parte del Estado competente para conocer de la solicitud de protección internacional, se expongan los "motivos fundados" sobre los que se sustenta la aplicación de la "cláusula de exclusión”»(FJ 11, in fine). 
10. A partir de estos criterios, el Tribunal encuentra en el Informe presentado por el CNI, el 24 de mayo de 2013, inseguridad y ambigüedad, por cuanto el mismo Informe alude a la escasa fiabilidad de los datos que expone y, además, valora la peligrosidad por su presunta vinculación con delitos de criminalidad organizada, pero no en relación con la actividad o influencia que pudiera desarrollar en España. Por otra parte, la Sala apuntó que el objeto del procedimiento se limitaba a la decisión sobre la solicitud de protección internacional, sin que su objeto estuviera afectado por las actuaciones vinculadas con el procedimiento de extradición, si bien, en un obiter dictum recordó el pronunciamiento del TEDH de 7 de julio de 1989, en el caso Soering c. $R$. $U$., en el que se afirmó la obligación de no extraditar a una persona que se enfrente a un riesgo real de ser sometida a tortura o penas y tratos inhumanos o degradantes en el estado solicitante (FJ 12).

11. En última instancia, la consecuencia de la declaración de nulidad de la Resolución impugnada no fue el reconocimiento de estatuto de refugiado, puesto que la AN consideró que al aplicar esta especie de inadmisión, la administración no había evaluado la solicitud siguiendo los criterios recogidos en la Ley del Asilo y la Directiva (FJ 13). En cambio, en el voto particular de dos de los magistrados de la Sala consideraban que la decisión no sólo debía sino que existían elementos suficientes en el expediente para que el Tribunal reconociera el estatuto de refugiado, en lugar de retrotraer el expediente para que sea decidido por la administración. En definitiva, al margen de las repercusiones políticas y mediáticas del presente asunto, la decisión ha aplicado adecuadamente el criterio, relativamente indeterminado, de la seguridad nacional, garantizando el equilibrio entre los intereses del Estado y los de los solicitantes de protección internacional.

Javier LASO PÉREZ

Universidad de Salamanca

http://dx.doi.org/10.17103/redi.67.1.2015.3a.06

\subsection{El valor de la documentación frente a la realidad física para determinar la edad de un menor extranjero no acompañado}

MENORES EXTRANJEROS NO ACOMPAÑADOS.-Valor de la documentación para la determinación de la edad.-Discrepancia con la realidad física.

Sentencia del Tribunal Supremo de 23 de septiembre de 2014 (Sala de lo Civil, Sección 1. ${ }^{a}$ ROJ: STS 3818/2014). Ponente: José Antonio Seijas Quintana.

\section{Referencia CentrodeDocumentación Judicial(Id.Cendoj) 28079119912014100014.}

1. En su Sentencia de 23 de septiembre de 2014, el TS abordó una cuestión en materia de extranjería con una trascendencia práctica de especial importancia para el respeto de los derechos de los menores extranjeros no acompañados. En particular, se trata de la determinación del valor que tiene la documentación que porta un menor extranjero no acompañado para determinar su edad cuando dicha documentación resulta ser contradictoria con su realidad física. Por tanto, no estamos ante una situación de indocumentación ni de invalidez de la documentación, sino que el problema radica en determinar la eficacia probatoria de la documentación que porta el menor a la hora de determinar su edad.

2. En el caso de autos, la determinación de la edad era relevante porque de ello dependía la aplicación o no del régimen de protección de menores del art. 780 de la 
Ley de Enjuiciamiento Civil (LEC). El 2 de septiembre de 2009, la Dirección de Atención a la Infancia y Adolescencia del Departamento de Acción Social y Ciudadanía de la Generalitat de Cataluña había dictado una resolución por la que cesaba el ejercicio de funciones tutelares asumidas con carácter preventivo, se dejaba sin efecto la guarda otorgada a la directora del centro de acogida y se cerraba el expediente de amparado de una joven ghanesa al considerar que tanto de su pasaporte como de su partida de nacimiento se concluía que era mayor de edad. Además, al estar en posesión de dicha documentación, la Administración entendió que no procedía la realización de pruebas médicas para confirmar la edad. En primera instancia, el Juzgado estimó la demanda en su totalidad, si bien la Audiencia Provincial de Barcelona estimó el recurso de apelación presentado por el Ministerio Fiscal, sobre la base del criterio, sostenido por la misma Audiencia en varias ocasiones, de que no ha de pronunciarse sobre la validez del documento aportado sino valorar la eficacia probatoria del mismo para determinar la edad de un menor. Así, consideró que el certificado de nacimiento de Ghana no tiene la consideración de documento público al no existir convenio al respecto con España ni al estar legalizado. Asimismo, justifica la práctica de la prueba pericial de la que se puede concluir que la edad de la joven es superior a los dieciocho años, lo que la privaría del derecho a la protección dispensada en España a los menores en situación de desamparo.

3. El interés del caso y la importancia de la sentencia del TS radican en el hecho de que existen pronunciamientos contradictorios de Audiencias Provinciales a la hora de determinar el valor de la documentación que portan menores extranjeros en nuestro país cuando contienen datos que no coinciden con la realidad física de la persona. En otras palabras, el TS se encuentra aquí en la tesitura de aportar una solución en los casos en los que existe una discrepancia entre la documentación y la realidad física de un menor extranjero no acompañado.

4. En opinión del TS, la normativa sustantiva aplicable al caso de autos, a saber, la Ley de Extranjería 4/2000 y su Reglamento de desarrollo, es suficientemente clara para ofrecer una solución, a pesar de lo cual la Audiencia Provincial de Barcelona realizó una interpretación errónea de la misma. El TS inicia su razonamiento con la naturaleza y la función del pasaporte como documento con validez internacional y con el uso que los funcionarios deben darle a los pasaportes extranjeros en España. En este sentido, es claro para el Tribunal que no corresponde a los funcionarios encargados de la recepción de tales pasaportes determinar su validez, la cual depende de los Convenios internacionales, al margen de la consideración que pueda tener en España como documento público o no, una vez cumplidos los requisitos exigidos en el país de origen y contengan datos suficientes sobre la identidad y la nacionalidad de su titular.

5. A continuación, el TS entra a analizar lo que dispone la normativa española en materia de extranjería en relación con la identificación y documentación de los extranjeros y de los menores, en particular los arts. 35.3 y 25.1 de la Ley de Extranjería, y 6 y 190 del Reglamento de desarrollo, de los que la Audiencia Provincial realizó una errónea interpretación. Según el TS, «[1]a correcta interpretación de los artículos de la Ley y Reglamento de Extranjería permite mantener que el inmigrante de cuyo pasaporte o documento equivalente de identidad se desprenda su minoría de edad no puede ser considerado un extranjero indocumentado para ser sometido a pruebas complementarias de determinación de su edad, pues no cabe cuestionar sin una justificación razonable por qué se realizan tales pruebas cuando se dispone de un pasaporte legalmente expedido por el país de origen cuya validez no ha sido cuestio- 
nada ni ha sido invalidado por ningún organismo competente. Se hace necesario, por tanto, realizar un juicio de proporcionalidad y ponderar adecuadamente las razones por las que se considera que el documento no es fiable y que por ello se debe acudir a las pruebas de determinación de la edad, lo que no se ha hecho».

6. A mayor abundamiento, el TS lleva a cabo un desarrollo específico de la cuestión de la realización de las pruebas médicas para la determinación de la edad. En este sentido, señala que «ya se trate de personas documentadas como indocumentadas, las pruebas médicas para la determinación de la edad, especialmente si son invasivas, no podrán aplicarse indiscriminadamente para la determinación de la edad, con la precisión de que cualquier duda sobre la minoría de edad basada en la simple apariencia física de la persona deberá resolverse a favor del menor, habida cuenta el hecho de que las técnicas actuales no permiten establecer con total precisión la edad». Por tanto, el TS concede una prioridad absoluta al interés del menor y su protección por las autoridades correspondientes en situaciones de desamparo en casos de duda sobre la determinación de su edad. Para ello, se apoya también en la Resolución del Parlamento Europeo, de 12 de septiembre de 2013, sobre la situación de los menores no acompañados en la UE [2012/2263 (INI)]. En consecuencia, el TS establece de forma clara y contundente que el interés superior del menor «debe prevalecer sobre cualquier otra consideración en todos los actos adoptados en este ámbito, tanto por las autoridades públicas como por las instituciones privadas».

7. Por todo ello, el Tribunal afirma que la joven ghanesa no sólo no se trata da una menor indocumentada, sino que además su documentación acredita su edad, por lo que su minoría de edad no podría ponerse en duda a los efectos de la normativa aplicable, y menos aún sin haber impugnado la validez de dichos documentos. Así, la joven «deberá quedar bajo la protección que la ley dispensa a los menores no acompañados».

8. De este modo, el TS sienta como doctrina jurisprudencial que «el inmigrante de cuyo pasaporte o documento equivalente de identidad se desprenda su minoría de edad no puede ser considerado un extranjero indocumentado para ser sometido a pruebas complementarias de determinación de su edad, pues no cabe cuestionar sin una justificación razonable por qué se realizan tales pruebas cuando se dispone de un pasaporte válido. Por tanto, procede realizar un juicio de proporcionalidad y ponderar adecuadamente las razones por las que se considera que el documento no es fiable y que por ello se debe acudir a las pruebas de determinación de la edad. En cualquier caso, ya se trate de personas documentadas como indocumentadas, las técnicas médicas, especialmente si son invasivas, no podrán aplicarse indiscriminadamente para la determinación de la edad» (apdo. 4 del fallo).

9. En fin, nos encontramos ante una doctrina, ya reiterada en una sentencia dictada al día siguiente por la misma Sala y Sección (STS 3817/2014), que permite establecer un criterio jurisprudencial único en todo el territorio nacional para salvaguardar los derechos de los menores extranjeros no acompañados, garantizando tanto su protección por instituciones públicas en casos de desprotección como la imposibilidad de someterles indiscriminadamente a pruebas médicas especialmente intrusivas o invasivas que pueden resultar traumatizantes. 


\section{7. «Devoluciones en caliente» de ciudadanos extranjeros a Marruecos}

\section{«DEVOLUCIONES EN CALIENTE» de ciudadanos extranjeros a Marruecos.- Concepto de frontera.-Devolución.-Legislación de extranjería.-Acuerdo de readmisión.}

\section{Auto del Juzgado de Primera Instancia e Instrucción núm. 2 de Melilla, de 11 de septiembre de 2014 (ROJ: AJPII 14/2014).}

\section{Referencia Centrode Documentación Judicial(Id.Cendoj) 52001410022014200001.}

1. El presente comentario analiza el Auto del Juzgado de Primera Instancia e Instrucción núm. 2 de Melilla, de 11 de septiembre de 2014. Las resoluciones de estos órganos judiciales no suelen ser objeto de atención en esta Crónica, salvo cuando nos hallemos - como ocurre en este caso- ante un pronunciamiento de especial relevancia en virtud de la importancia otorgada por el juez al Derecho internacional en su argumentación.

2. El auto en cuestión se relaciona con una temática de gran actualidad e interés jurídico-político como es la controvertida práctica de las denominadas «devoluciones en caliente», consistente en la entrega de ciudadanos extranjeros recién llegados a territorio español a las autoridades marroquíes, sin seguir ningún tipo de procedimiento administrativo, ni respetar las garantías correspondientes, de conformidad con la legislación española de extranjería y las obligaciones asumidas por nuestro país en materia de derechos humanos (véase MARTínEz EsCAMILla et al., "Expulsiones en caliente": Cuando el Estado actúa al margen de la ley», 27 de junio de 2014, disponible en http://eprints.ucm.es/25993/).

3. La práctica de devoluciones sumarias en la frontera hispano-marroquí se acompaña, lamentablemente, de sucesos trágicos, destacando, por ejemplo, los acaecidos en Ceuta en febrero de 2014 cuando un numeroso grupo de migrantes trató de bordear por el agua el espigón fronterizo que separa las partes española y marroquí de la playa del Tarajal. Una quincena de personas fallecieron por ahogamiento como consecuencia de los disparos de material antidisturbios por parte de la Guardia Civil, mientras otros migrantes eran entregados directamente a la gendarmería marroquí (El País, "La Guardia Civil calcula que fallecieron 14 inmigrantes en el espigón de Ceuta», 7 de febrero de 2014. Los hechos están siendo objeto de investigación por parte del Juzgado de Instrucción núm. 6 de Ceuta). Asimismo, se han venido denunciando casos de violencia policial en la represión de los saltos a las vallas fronterizas, como ocurrió en Melilla, en octubre de este mismo año (El Mundo, «La ONG Prodein denuncia que la Guardia Civil devolvió a Marruecos a un inmigrante gravemente herido», 16 de octubre de 2014).

4. En particular, los hechos relativos al auto objeto de comentario, denunciados por la Federación Andalucía Acoge, la Federación de Asociaciones SOS Racismo del Estado español y PRODEIN, tuvieron lugar en la valla fronteriza de Melilla, los días 18 de junio y 13 de agosto de 2014. En las grabaciones aportadas por los denunciantes, se observa cómo varios ciudadanos subsaharianos, después de saltar la valla, son entregados de forma inmediata a las fuerzas de seguridad marroquíes sin aplicarles la legislación española de extranjería. Por ello, el auto trata de aclarar si se produjeron dichas entregas y si, de ser el caso, nos hallaríamos ante una infracción penal.

5. Entre las cuestiones jurídicas que aborda el auto y que guardan relación con el Derecho internacional público, hemos de partir del concepto y la naturaleza jurídica 
de la frontera, en tanto que línea de delimitación de los respectivos ámbitos territoriales de ejercicio de las competencias estatales (en relación con las funciones de la frontera y la afectación de la noción por el Derecho de la UE, véase DEL VALLE GÁLVEz, A., «Las fronteras de la Unión - El modelo europeo de fronteras», Revista de Derecho Comunitario Europeo, 2002, núm. 12, pp. 299-341) y de la particular configuración de los medios de protección de la frontera terrestre en las Ciudades Autónomas de Ceuta y Melilla. En efecto, resulta esencial para comprender el análisis que se acomete en el auto comentado recordar cómo se inicia, desde mediados de los años noventa, la construcción de estructuras metálicas complejas que bordean Ceuta y Melilla en sus fronteras con Marruecos. El vallado, compuesto de una valla exterior y otra interior, se eleva a seis metros de altura, cuenta con cámaras térmicas, torres de vigilancia, sensores, mallas "antitrepa» y una sirga tridimensional entre ambas vallas, estando además protegido por las controvertidas concertinas, retiradas en 2007 por su peligrosidad y reintroducidas de nuevo en 2013 (para más detalles, véase APDHA, Derechos Humanos en la Frontera Sur 2014, marzo de 2014, disponible en http://www.apdha.org/ medialfrontera_sur_2014_web.pdf (u.a. 22 de diciembre de 2014).

6. La cuestión a resolver reside así en determinar si los migrantes que saltaron la valla de Melilla de tales características llegaron a entrar en suelo español, siéndoles, por tanto, de aplicación la legislación española de extranjería. De ahí que, en primer lugar, el auto se centre en clarificar la delimitación de las fronteras entre España y Marruecos, determinada, como explica el juez, en distintos tratados internacionales, concretamente en el Convenio relativo a la delimitación de las fronteras españolas con Marruecos en las plazas de Ceuta y Melilla, de 24 de agosto de 1859, el Acta de demarcación de los límites de la plaza de Melilla, de 26 de junio de 1862, el Acuerdo relativo a la conservación de los límites de la plaza de Melilla, de 14 de noviembre de 1863 y, finalmente, el Tratado de Paz y Amistad entre España y Marruecos, de 26 de abril de 1860. Este último es empleado por el juzgador para argumentar que el terreno entre las vallas no forma parte de la frontera, sino que constituye territorio español bajo soberanía española. El doble vallado y la sirga tridimensional han de incluirse, según el auto, en el concepto de «fortificaciones y defensas» adoptadas por España y sujetos a su soberanía en el sentido del art. 7 del mencionado Tratado, que permitía a España adoptar tales medidas de seguridad sin que las autoridades marroquíes opusieran obstáculo alguno. La frontera quedará, por tanto, delimitada por la valla exterior del complejo fronterizo, a partir de la cual será de aplicación la legislación española sin limitación alguna (FJ 2).

7. Sin embargo, el concepto de frontera empleado por la Comandancia de la Guardia Civil de Melilla no es el mismo, toda vez que se defiende la aplicación de un «concepto operativo de frontera», consolidado desde 2005 — cuando se inicia la crisis migratoria en España- y explicitado en la Orden de servicio 6/2014 del coronel jefe de la Comandancia de la Guardia Civil de Melilla. En virtud de este concepto operativo, sería la valla interna la que materializa, a los solos efectos de extranjería, la línea de delimitación del territorio nacional. En consecuencia, el cruce de la valla externa no constituye, según la Orden citada, una entrada ilegal en territorio español, consumándose ésta únicamente cuando se cruza la valla interna y aplicándose, a partir de la misma, la legislación española de extranjería y, más concretamente, la figura de la devolución, regulada en el art. 58 de la LO 4/2000 sobre derechos y libertades de los extranjeros en España y su integración social (modificada sucesivamente por las LO 8/2000, 14/2003 y 2/2009, en adelante LOEx) y en el art. 23 del Reglamento de extranjería (Real Decreto 557/2011, de 20 de abril, por el que se aprueba el Reglamento de la LO 4/2000, sobre derechos y libertades de los extranjeros en España y su inte- 
gración social, tras su reforma por LO 2/2009, BOE núm. 103, de 30 de abril de 2011, en adelante RLOEx).

8. Conforme a dichos preceptos normativos, la devolución se aplica en dos supuestos: a los extranjeros que, tras ser expulsados, contravengan la prohibición de entrada en España, y a los extranjeros que pretendan entrar irregularmente en el país, incluyendo a los interceptados en la frontera o sus inmediaciones. Centrando nuestro interés en este segundo supuesto, la legislación española prevé que los agentes de las Fuerzas y Cuerpos de Seguridad del Estado, que hayan interceptado a extranjeros intentando entrar irregularmente en España, deberán conducirlos lo antes posible a la correspondiente comisaría de policía para que pueda procederse a su identificación y, en su caso, a su devolución (art. 23.2 RLOEx). La devolución se erige así en una alternativa a la apertura de un expediente de expulsión aplicable a aquellos que se encuentren irregularmente en territorio español [art. 57 en relación con el art. 53.1.a) LOEx] y distinta también de la denegación de entrada aplicable a los que, presentándose en un puesto fronterizo, no cumplan con los requisitos de entrada (art. 26.2 LOEx). Ahora bien, la devolución exige igualmente cumplir con ciertas formalidades y garantías, como la adopción de una resolución del Subdelegado del Gobierno o Delegado del Gobierno en Comunidades Autónomas uniprovinciales, la concesión del derecho a la asistencia jurídica y la asistencia de intérprete - ambas gratuitas en caso de que el individuo carezca de recursos económicos suficientes (art. 22.2 LOEx y art. 23.3 RLOEx) - o el derecho a recurrir contra la resolución administrativa [art. 23.4 RLOEx. Respecto de la configuración y efectos de la devolución, nos remitimos a Moya MaLAPEIRA, D. y HeRnÁndez CALERO, D., «Los controles en frontera: denegación de entrada, orden de regreso y devolución», en Boza Martínez, D., Donaire Villa, F. J. y Moya MALAPEIRA, D. (coords.), La nueva regulación de la inmigración y la extranjería en España. Régimen jurídico tras la LO 2/2009, el Real Decreto 557/2011 y la Ley 12/2009, Valencia, Tirant lo Blanch, 2012, pp. 192-226, en especial pp. 220 y ss.]. Y, lo que es más importante, la ejecución de la resolución de devolución quedará suspendida cuando el extranjero formalice una solicitud de protección internacional y hasta que ésta se resuelva o no sea admitida, de conformidad con la Ley 12/2009, de 30 de octubre, reguladora del derecho de asilo y de la protección subsidiaria (BOE núm. 263, de 31 de octubre de 2009), en concreto su art. 19.1 (art. 58.4 LOEx y art. 23.6 RLOEx).

9. Dado que el concepto operativo de frontera desvirtúa el límite jurídico del territorio español, dando lugar a una franja de tierra entre las vallas que constituiría tierra de nadie, las autoridades gubernamentales pretenden evitar así la aplicación del procedimiento de devolución y, por consiguiente, las garantías requeridas por la legislación española a los extranjeros que intentan acceder a su territorio. Todo ello, además, resulta aún más grave en el caso de los hechos abordados en el auto objeto de comentario, puesto que sus protagonistas, según se desprende de las grabaciones, habrían llegado a sobrepasar el doble vallado, incluida la valla interna, por lo que habrían entrado en territorio español en base al propio concepto operativo de frontera sostenido por el Gobierno.

10. El auto muestra de este modo cómo nos hallamos ante dos conceptos de frontera, uno de naturaleza jurídica, conforme a los tratados internacionales entre España y Marruecos, y otro de carácter operativo o funcional, que responde a un criterio gubernamental, político o de simple operatividad policial (FJ 3; nótese que, si la valla interna en Ceuta y Melilla materializa, según el Gobierno, la delimitación fronteriza a efectos de extranjería, sería la barrera de agentes de la Guardia Civil la que se erige en línea fronteriza imaginaria en el caso de las playas como se desprende del «Informe 
incidentes frontera de Ceuta, día 6 de febrero de 2014», Dirección Adjunta Operativa de la Guardia Civil, 8 de febrero de 2014).

11. A continuación, el juez recuerda el art. 96.1 de la Constitución española por el que los tratados internacionales válidamente celebrados y una vez publicados oficialmente en España formarán parte de nuestro ordenamiento interno, sin que puedan ser derogados, modificados o suspendidos más que en el modo previsto en el tratado o conforme al Derecho internacional general. De esta manera, el precepto constitucional que consagra la solución del monismo moderado en las relaciones entre el Derecho internacional y nuestro Derecho interno sirve al juez para excluir la legalidad del concepto operativo de frontera. Dicho concepto, el cual no se ampara en ninguna norma jurídica y que, por tanto, vulnera también, como indica el auto, lo previsto en el art. 9.3 de la Constitución, supone «una derogación de facto de los tratados internacionales suscritos entre ambos países en materia de delimitación de los límites fronterizos, ya que no se aplicó la legislación española en materia de extranjería» a aquellas personas que saltaron la valla de Melilla (FJ 4). En efecto, no puede el Gobierno español proceder unilateralmente a delimitar el espacio territorial sujeto a la jurisdicción soberana española, ni reducir el ámbito de aplicación espacial de una ley sin respetar las exigencias constitucionales, ni tampoco declarar el carácter de no man's land de una franja correspondiente a su territorio (por analogía, nos remitimos al excelente trabajo de DEL VALle Gálvez, A. "Las zonas internacionales o zonas de tránsito de los aeropuertos, ficción liminar fronteriza», Revista Electrónica de Estudios Internacionales, 2005, núm. 9, pp. 1-18, donde se afirma que, si bien la ficción jurídica fronteriza de las zonas de tránsito de los aeropuertos es comprensible técnicamente, no puede implicar que se niegue la condición de territorio del Estado a las mismas, excluyendo la aplicación del Derecho nacional).

12. Ciertamente, España y Marruecos mantienen una estrecha cooperación transfronteriza entre sus servicios de policía, como se pone de manifiesto en otros acuerdos internacionales y arreglos informales suscritos entre ambos países y relativos a la cooperación policial en la prevención y represión de diversas formas de criminalidad, incluida la inmigración irregular (véase, por ejemplo, el Acuerdo entre el Gobierno del Reino de España y el Gobierno del Reino de Marruecos en materia de cooperación policial transfronteriza, hecho ad referendum en Madrid el 16 de noviembre de 2010, BOE núm. 116, de 15 de mayo de 2012), o el establecimiento de patrullas conjuntas de control de fronteras desde finales de 2003 (El País, «Guardias civiles patrullarán con gendarmes en Marruecos para impedir la salida de pateras», 5 de diciembre de 2003). Ahora bien, estos compromisos no prejuzgan la aplicación de la legislación española de extranjería, ni tampoco el respeto de las obligaciones internacionales de protección de los derechos humanos asumidas por los Estados implicados y que resulten de aplicación. Nótese, además, que, en todo caso, el sometimiento de la actuación de los poderes públicos a dichas obligaciones de respeto de los derechos humanos no se produce únicamente cuando su actividad se desarrolle en territorio español, sino que es el criterio de jurisdicción el que incluirá también cualquier actuación de agentes del Estado que, realizada fuera de su territorio, suponga el ejercicio de control y autoridad sobre los individuos, titulares de los derechos a proteger (véase Martínez Escamilla et al., "Expulsiones en caliente”...», op. cit., p. 9. Para la aplicación extraterritorial del CEDH, véase, en particular, Hirsi Jamaa y otros c. Italia, Sentencia de 23 de febrero de 2012, núm. 27765/09).

13. Al valorar los hechos a través de las pruebas correspondientes (a estos efectos, el auto se refiere asimismo a la jurisprudencia del TEDH en relación con la admi- 
sión de las diligencias probatorias y la necesidad de ponderar si el medio de prueba empleado por el juzgador es pertinente, necesario y posible, FJ 6), el juez indica que ninguno de los extranjeros fue trasladado a las dependencias de la Jefatura Superior de la Policía Nacional de Melilla —algunos estaban incluso lesionados—, infringiendo lo exigido por la legislación de extranjería (art. 23.2 del RLOEx) y el Acuerdo de readmisión entre España y Marruecos de 1992.

14. En efecto, el auto también reproduce y analiza el Acuerdo entre el Reino de España y el Reino de Marruecos relativo a la circulación de personas, el tránsito y la readmisión de extranjeros entrados ilegalmente, firmado en Madrid el 13 de febrero de 1992 (de aplicación provisional desde su firma, BOE núm. 100, de 25 de abril de 1992, y en vigor desde el 21 de octubre de 2012, BOE núm. 299, de 13 de diciembre de 2012). Así, entiende el juez que este tratado ha sido vulnerado al no observarse las mínimas garantías previstas en el mismo para proceder a la readmisión en forma, como son la petición formal de las autoridades fronterizas del Estado requirente; la presentación de la solicitud en los diez días posteriores a la entrada ilegal, haciendo constar en ella la identidad del individuo, su documentación personal y sus condiciones de entrada; o la expedición, en caso de aceptación, por parte del Estado requerido de un certificado o cualquier otro documento que haga constar la identidad y la documentación poseída en su caso por el extranjero (FJ 6). En este sentido, pese a la pertinencia de la mención del Acuerdo, es necesario destacar que, a la vista de su naturaleza jurídica, los acuerdos de readmisión tienen por finalidad permitir la ejecución de la repatriación de inmigrantes, cuya salida del territorio español haya sido previamente ordenada en virtud de la legislación interna de extranjería. En consecuencia, la aplicación del acuerdo de readmisión y la observancia de sus garantías se producirá una vez que las autoridades españolas hayan adoptado una decisión administrativa que obligue a la salida del extranjero del territorio nacional (no obstante, la DA 6. ${ }^{a}$ de la LOEx parece prever la aplicación directa de los acuerdos de readmisión celebrados por España a aquellos extranjeros que entren en sus respectivos ámbitos de aplicación, lo que resulta, a nuestro entender, ciertamente controvertido). Concluye el juez que, como consecuencia de los hechos que han sido objeto de comprobación en los razonamientos jurídicos del auto, la manera de actuar de las autoridades españolas podría ser constitutiva de infracción penal y, más concretamente, de un delito de prevaricación previsto en el art. 404 del Código Penal, ordenando, en consecuencia, la imputación del coronel jefe de la Comandancia de la Guardia Civil de Melilla por ser la persona que dictó, a sabiendas de su supuesta injusticia, la Orden de Servicio 6/2014 y por estar al mando del dispositivo que procede a su ejecución (FJ 7).

15. El auto cuestiona así la legalidad de la práctica de las «devoluciones en caliente», centrándose en el concepto de frontera y su delimitación, operada por tratados internacionales de los que España es Parte, así como en el Acuerdo de readmisión entre España y Marruecos y las garantías mínimas que éste establece. No obstante, en aras de una mayor exhaustividad, cabría afirmar que las «devoluciones en caliente» vulneran, además de los tratados mencionados y la legislación española de extranjería ya comentada, otras normas de Derecho internacional como las derivadas de las obligaciones asumidas por España en materia de protección de los derechos humanos, entre las que cabría citar las contenidas en el CEDH y, en particular, en los arts. 3 y 13 del Convenio y el art. 4 del Protocolo núm. 4 al CEDH relativo a las expulsiones colectivas, así como la Convención de Ginebra sobre el Estatuto de los Refugiados de 1951 o los arts. 4, 18, 19 y 47 de la Carta de Derechos Fundamentales de la UE. Sin olvidar la posible vulneración de normas del Derecho derivado de la UE, como el Re- 
glamento núm. 562/2006, del Parlamento Europeo y del Consejo, de 15 de marzo, por el que se establece un Código comunitario de normas para el cruce de personas por las fronteras (Código de fronteras Schengen) (DO L 105, de 13 de abril de 2006, p. 1. La Declaración del Reino de España relativa a las ciudades de Ceuta y Melilla, que figura en el Acta final del Acuerdo de adhesión de España al Convenio de aplicación del Acuerdo de Schengen de 1985 no resulta relevante a los efectos que son objeto de nuestra atención), la Directiva 2008/115, del Parlamento Europeo y del Consejo, de 16 de diciembre, relativa a normas y procedimientos comunes en los Estados miembros para el retorno de los nacionales de terceros países en situación irregular ( $D O$ L 348, de 24 de diciembre de 2008, p. 98; nótese que la posibilidad, prevista por su art. 2.2, de no aplicar la Directiva a los detenidos o interceptados con ocasión del cruce de una frontera exterior no prejuzga la concesión de un trato no menos favorable al previsto en la Directiva respecto de ciertas garantías mínimas, ni el respeto del principio de no devolución en virtud del art. 4.4 de la misma norma) o la Directiva 2013/32, del Parlamento Europeo y del Consejo, de 26 de junio, sobre procedimientos comunes para la concesión o la retirada de la protección internacional ( $D O$ L 180, de 29 de junio de 2013, p. 60). Así, la incompatibilidad con el Derecho de la UE y el Derecho internacional de los derechos humanos de la práctica de las devoluciones sumarias llevada a cabo por España ha provocado las críticas de instituciones como el Comité de Derechos Humanos de Naciones Unidas, ACNUR, el Consejo de Europa o la Comisión Europea, especialmente preocupados por los intentos del Gobierno de legalizar la práctica de las «devoluciones en caliente» a través de la reforma de la ley de seguridad ciudadana.

16. En este sentido, el pasado 11 de diciembre, el Congreso de los Diputados aprobó el proyecto de Ley Orgánica de protección de la seguridad ciudadana, por el cual se añade, en virtud de su disposición final 1. a , una disposición adicional 10. a a la LOEx relativa al régimen especial de Ceuta y Melilla, con la siguiente redacción: «Los extranjeros que sean detectados en la línea fronteriza de la demarcación territorial de Ceuta o Melilla mientras intentan superar, en grupo, los elementos de contención fronterizos para cruzar irregularmente la frontera podrán ser rechazados a fin de impedir su entrada ilegal en España» (Proyecto de Ley Orgánica de protección de la seguridad ciudadana, 121/000105, Dictamen de la Comisión, BOCG Congreso de los Diputados, Serie A, núm. 105-4, de 3 de diciembre de 2014, aprobado por el Congreso el 11 de diciembre de 2014 y objeto de tramitación en el Senado).

17. Con esta modificación, se pretende que a aquellos que intenten cruzar la frontera en Ceuta o Melilla no se les aplique la devolución prevista en la legislación de extranjería, sino «el rechazo en frontera», nueva figura que no parece llevar aparejada ninguna de las garantías correspondientes a las denegaciones de entrada (arts. 26.2 y 60 LOEx y art. 15 RLOEx) o las devoluciones ya comentadas. Se deduce de sus términos que el rechazo consistirá simplemente en obligar al extranjero a retroceder, impidiéndole cruzar la frontera. Ahora bien, el nuevo precepto no aclararía qué ha de entenderse por línea fronteriza. Lo que sí resulta claro es que esta reforma impropia de la legislación de extranjería pretende legalizar las «devoluciones en caliente», generando una norma que se erige en lex specialis para la frontera española en Ceuta y Melilla. La definitiva aprobación de esta nueva disposición legislativa supondría poner negro sobre blanco que el Gobierno español contraviene la prohibición de expulsiones colectivas de extranjeros, constituyendo además un claro obstáculo a la identificación y protección de refugiados y otras personas en situación de vulnerabilidad en contra de los compromisos internacionales asumidos por el Estado español. Ante esta situación, pronunciamientos como el auto aquí comentado 
han de ser bienvenidos al generar, al menos, cierta confianza en uno de los poderes del Estado.

\author{
Paula GARCía ANDRADE \\ Universidad Pontificia Comillas \\ http://dx.doi.org/10.17103/redi.67.1.2015.3a.08
}

\title{
3.8. Ejecución de sentencias del Tribunal Europeo de Derechos Humanos \\ CONVENIO EUROPEO DE DERECHOS HUMANOS.-Ejecución de sentencias del TEDH.-GARANTÍAS Y DERECHO A UN PROCESO JUSTO.-Derecho a la tutela judicial efectiva.
} Auto del Tribunal Supremo (Sala de lo Penal), de 5 de noviembre de 2014 (ROJ:
ATS 8256/2014). Ponente: Joaquín Giménez García.

\section{Referencia Centrode DocumentaciónJudicial(Id.Cendoj) 28079120012014202142.}

[...] Adriano pretende autorización necesaria para interponer recurso extraordinario de revisión y dice que el 9 de septiembre 2005 la Audiencia Provincial de Castellón dictó sentencia en la causa absolviendo al recurrente del delito contra el medio ambiente. Contra la anterior sentencia la acusación particular recurre en casación y por sentencia de 19 de octubre 2006 de esta Sala Casacional 1091/2006 se estima el recurso y condena a Adriano como autor de un delito medioambiental a la pena de dos años de prisión y veinticuatro meses de multa a razón de una cuota por día que se fija en 400 euros. El recurrente acude en amparo al Tribunal Constitucional que inadmite el recurso. Agotadas las vías internas, el penado acudió al Tribunal de Derechos Humanos presentando demanda contra el Reino de España por vulneración de los arts. 6 y 7 del Convenio Europeo para la protección de los Derechos Humanos y Libertades Fundamentales por entender que no era posible variar la sentencia absolutoria en condenatoria efectuando una valoración de pruebas sin la inmediación de la que no dispuso el Tribunal Supremo. El TEDH en sentencia de 27 de noviembre de 2012 estimó la violación del art. 6.1 del Convenio Europeo.

En base a esta sentencia y con apoyo en el art. 954.4 LECriminal, solicita autorización para la revisión de la sentencia dictada por esta Sala 1091/2006 de 19 de octubre.

1. Mediante el presente auto, el TS resuelve autorizar recurso extraordinario de revisión conforme al art. 954.4 de la LECrim. bajo el argumento de que la sentencia del TEDH que condena a España por la vulneración del art. 6.1 del CEDH constituye un hecho nuevo que evidencia la inocencia del condenado y que justifica la apertura de dicho recurso de revisión (asunto Vilanova Goterris y Llop García c. España, núms. 5606/09 y 17516/09, de 27 de noviembre de 2012).

2. El comentario se enmarca dentro de dos cuestiones de significativa relevancia y actualidad aún irresueltas en el plano normativo español. Por un lado, plantea el problema de la ejecución directa de las sentencias del TEDH en nuestro ordenamiento cuando dicho Tribunal declara la vulneración de alguna de las disposiciones del CEDH por parte de España. A esta primera cuestión es a la que da respuesta concreta el auto analizado. A ello se añade el problema suscitado por el dudoso encaje del proceso penal español —que no admite la vista pública en segunda instancia - con el derecho a un proceso equitativo recogido en el art. 6 del CEDH. Precisamente, cabe recordar que la mayor parte de las sentencias condenatorias de España por el Tribunal de Estrasburgo constatan la vulneración de alguno de los derechos subjetivos 
contenidos en el genérico derecho a un proceso equitativo. Con todo, la sentencia del TEDH se ciñe a evaluar el caso concreto, de manera individualizada, sin entrar a cuestionar el sistema procesal interno.

3. Para examinar los dos problemas jurídicos que se presentan como más evidentes de la lectura del auto referido, conviene reseñar algunos de los razonamientos contenidos en la sentencia del TEDH (Sección 3. ${ }^{a}$ ): «[...] Mediante Sentencia de 25 de septiembre de 2005, dictada tras la celebración de una vista pública en presencia de los demandantes, la Audiencia Provincial de Castellón absolvió al primer demandante de un delito de prevaricación medioambiental y de otro de denegación de auxilio y al otro demandante de un delito contra el medio ambiente» (apdo. 6). La sentencia de la Audiencia Provincial fue recurrida en casación por la parte acusadora y así «mediante Sentencia del día 19 de octubre de 2006, dictada sin que se celebrara vista públi$c a$, el Tribunal Supremo anuló la sentencia recurrida y condenó a los demandantes» (apdo. 12) (cursiva añadida en ambos casos). Tras recurrir en amparo ante el Tribunal Constitucional e inadmitir éste el recurso por considerar que sus pretensiones carecen de contenido constitucional, los demandantes acuden al TEDH alegando que la falta de vista pública les impidió beneficiarse del derecho a un juicio equitativo según lo dispuesto en el art. 6.1 del CEDH.

4. El marco en el que se incardina el auto es, en sentido general, el del diálogo entre el TEDH y los tribunales nacionales, calificado por el Magistrado del Tribunal de Estrasburgo, López Guerra, en los términos siguientes: "[...] en lo que se refiere al diálogo entre el TEDH y los tribunales nacionales, éste versaría, no sólo sobre cómo esos tribunales aplican la jurisprudencia del TEDH, sino también sobre cómo el TEDH evalúa a su vez esa aplicación; y, yendo más allá, sobre cómo los diversos tribunales (tanto los nacionales como el de Estrasburgo) modifican sus posiciones previas, ante la reacción de sus interlocutores» («El diálogo entre el tribunal europeo de derechos humanos y los tribunales españoles. Coincidencias y divergencias», Teoría y Realidad Constitucional, 2013, núm. 32, pp. 139-158).

5. En el caso que nos ocupa, la Sala, movida por la obligación de dar entrada a la sentencia del TEDH, se muestra dispuesta a modificar su posición previa. Ahora bien, el ordenamiento español no le ofrece una respuesta legislativa al problema sobre cuál sería el cauce jurídico apropiado para dar entrada a las sentencias del TEDH que contradicen lo resuelto en el ámbito doméstico. Ciertamente, una vez asumido el compromiso de acatar las sentencias definitivas del TEDH (art. 46 del CEDH), lo complicado es ubicar el Convenio en el sistema de fuentes del Derecho español, pero sobre todo, asumirlo y ponerlo en práctica mediante la articulación de un procedimiento interno que responda adecuadamente a lo establecido en el Convenio.

6. Son conocidas y numerosas las contribuciones de la doctrina española sobre las carencias del sistema jurídico español en esta materia (entre otros, RiPOL CARULLA, S., El sistema europeo de protección de los derechos humanos y el Derecho espanol, Barcelona, Atelier, 2007). De todas ellas se infiere una llamada a la regulación legal de la cuestión. También la doctrina jurisprudencial construida por el TC y el TS para subsanar la insuficiencia legislativa es más que reseñable, y así lo recuerda la propia Sala de lo Penal en el auto analizado. Además de referirse a la ya conocida STC 245/1991 en el asunto Barberá, Messegué y Jabardo, el auto se remite sustancialmente a la teoría más concluyente y pormenorizada al respecto recogida en la Sentencia del TC 240/2005, de 10 de octubre, en la que afirma que dentro del concepto de «hecho nuevo, que evidencia la inocencia del condenado» del art. 954.4 LECrim. se engloban las sentencias del TEDH. 
7. El dilema de fondo radica en inclinarse por el derecho fundamental a la presunción de inocencia del art. 24.2 de la CE frente al valor de la seguridad jurídica derivada de la intangibilidad de las sentencias firmes. El TC entiende que al acreditarse hechos y circunstancias objetivas nuevas que evidencian la vulneración del debido proceso y la inocencia del condenado, prevalece el primero de los intereses en conflicto.

8. Ante la situación de omisión legislativa, que ya podría calificarse de irregular en España, y en aras a articular un cauce jurisprudencial propicio para absorber las sentencias del citado TEDH, el auto del TS analizado irrumpe con la afirmación que por categórica conviene recoger literalmente: «Sobre esta cuestión ya está superada la doctrina que sostenía que las SSTEDH solo tenían naturaleza declarativa y que por tanto no era posible anular la sentencia en la que se había apreciado la vulneración de los derechos reconocidos en el Convenio Europeo». Para sustentar esta afirmación, la Sala se refiere a la ratificación por España del Protocolo núm. 14 del CEDH que hace que la naturaleza vinculante de las sentencias del TEDH en el ordenamiento español esté «fuera de toda duda». En efecto, la nueva redacción del art. 46 del CEDH obliga a los Estados a acatar las sentencias del Tribunal de Estrasburgo y además, prevé textualmente que «la supervisión de la ejecución de las sentencias definitivas» corresponde al Comité de Ministros (art. 46.3 del Convenio) (cursiva añadida).

9. El art. 41 del CEDH, que ofrece la denominada «satisfacción equitativa» cuando el sistema de reparación del Estado resulta imperfecta, no resulta suficiente para satisfacer a los demandantes, cuyos antecedentes penales permanecerían inalterados. Por este motivo, la Sala opta por centrar su fundamentación en el art. 46 del Convenio aunque el Tribunal de Estrasburgo no se hubiera referido al mismo de manera expresa. A tenor de dicho art. 46, las sentencias de Estrasburgo «no solo tienen naturaleza declarativa», y en consecuencia, se reconoce la posibilidad de anular la sentencia del propio TS sobre la que se ha apreciado la vulneración del Convenio. Dicho de otro modo, el cumplimiento de la sentencia no se da por concluido a través del pago de la satisfacción equitativa, sino que también alcanza a la obligación de modificar la sentencia del tribunal interno declarada por el TEDH contraria a alguna de las disposiciones del Convenio.

10. En esta línea de argumentación, la Sala de lo Penal del TS también podía haberse valido de otros resortes para sostener su tesis. A tenor del CEDH se atribuye al Comité de Ministros la facultad de iniciar ante el Tribunal de Estrasburgo un procedimiento por incumplimiento de sentencia (art. 46.4).

11. Incluso, otro elemento que refleja la tendencia a exigir al Estado condenado la adopción de actos concretos es el denominado procedimiento piloto incorporado en el Reglamento del TEDH. Este es aplicable a las demandas que responden a problemas estructurales o sistémicos de un Estado miembro. El Tribunal, además de declarar la existencia de una vulneración del Convenio, fija las medidas que el Estado debe adoptar para remediar dicha violación.

12. Más allá del razonamiento que se desprende del propio CEDH y del Reglamento del Tribunal, la propia jurisprudencia del TEDH refleja la tendencia a superar el carácter meramente declarativo de sus sentencias así como a limitar la libertad de los Estados a elegir los medios para la ejecución de éstas. Entre nosotros, esto queda demostrado en los dos casos contra España en los que el TEDH ha utilizado el art. 46 del CEDH: las SSTEDH de 10 de julio de 2012 y de 21 de octubre de 2013 en el asunto 
Del Río Prada c. España (as. 42750/09) [véase al respecto, ANDRÉs SÁENZ DE SANTA MARÍA, P., «Acerca del papel del tribunal europeo de derechos humanos y de la tentación de desacreditar al mensajero (a propósito de la STEDH [Gran Sala] en el asunto del Río Prada c. España)», Teoría y Realidad Constitucional, 2014, núm. 33, pp. 199-218] y más recientemente, la Sentencia de 22 de abril de 2014 en el asunto A. C. y otros contra España (as. 6528/11).

13. A todo ello se añaden las Recomendaciones del Comité de Ministros en esta misma dirección, y también lo recogido en la Declaración de Interlaken, de 19 de febrero de 2010, en la que se subraya que la ejecución completa, efectiva y rápida de las sentencias del TEDH es indispensable.

14. Por otra parte, no es casual que con carácter previo a la adopción del auto, el Pleno no Jurisdiccional de la Sala de lo Penal del Tribunal Supremo adoptara por unanimidad un acuerdo en relación con las sentencias del TEDH, que establece textualmente: «En tanto no exista en el ordenamiento jurídico una expresa previsión legal para la efectividad de las sentencias dictadas por el TEDH que aprecien la violación de derechos fundamentales de un condenado por los tribunales españoles, el recurso de revisión del art. 954 de la Ley de Enjuiciamiento Criminal cumple este cometido» (21 de octubre de 2014).

15. Precisamente, el periodo de redacción del presente comentario coincide con la proceso de aprobación del Anteproyecto de la LECrim. (art. 954) que incluye como un nuevo motivo del recurso extraordinario de revisión las sentencias del TEDH en las que España resulta condenada. Se añaden por tanto como causa con entidad propia las sentencias del Tribunal. Ahora bien, la redacción de dicha previsión de lege ferenda dispone que tal recurso cabe «siempre que la violación haya sido relevante o determinante de la condena, sea actual y no pueda ser reparada de ningún otro modo que no sea la reapertura del proceso» (Anteproyecto de Ley Orgánica de Modificación de la Ley de Enjuiciamiento Criminal para la Agilización de la Justicia Penal, el Fortalecimiento de las Garantías Procesales y la Regulación de las Medidas de Investigación Tecnológicas, Ministerio de Justicia, de 5 de diciembre de 2014). Habrá que interpretar con cautela el significado de la "relevancia de la violación», puesto que el riesgo de esta solución es que toda sentencia del TEDH que condene a España por la violación del art. 6.1 del CEDH termine derivando en un recurso de revisión, cuando en realidad, el problema no es sólo el de los efectos de las sentencias del TEDH en el orden interno, sino que también es otro, que proviene de la estructura del orden procesal penal expuesta en el apartado siguiente de este comentario.

16. En el auto que nos ocupa, la queja principal de los recurrentes es la no celebración de vista pública en el recurso de casación ante el TS y, en consecuencia, el hecho de que dicho Tribunal valorara unos medios de prueba sin haberles oído previamente. Reivindican que no es posible variar la sentencia absolutoria en condenatoria sin la inmediación de la que no dispusieron. Ello les impide beneficiarse del derecho a un juicio equitativo. Sobre este punto planea la concepción constitucional del derecho a la tutela judicial efectiva y al debido proceso, así como los instrumentos de interpretación que lo acompañan derivados de la ratificación por España del Pacto de Derechos Civiles y Políticos de 1966 y del CEDH de 1950 (derecho a un juicio equitativo).

17. En efecto, al proscribirse la práctica de pruebas en segunda instancia, salvo las excepciones que no se dan en este caso, se pone en cuestión la vertiente interactiva del principio de inmediación. En este orden de cosas, frente a los dictámenes del 
Comité de Derechos Humanos de la ONU que condenan a España por este aspecto (Martínez Fernández c. España, de 29 de marzo de 2005, por citar uno de ellos), tanto el TC como el TS han negado que el art. 14.5 del PDCP imponga necesariamente la repetición íntegra del juicio ante el órgano ad quem (STC 116/2006, de 24 de abril, y Acuerdo del Pleno no jurisdiccional, de 13 de septiembre de 2000) (véase a este respecto, CABEzUdo, N., «Acceso a la justicia y garantías del debido proceso», en Rey, F. et al., Los derechos humanos en España, hoy Informe crítico) (en curso de publicación).

18. El problema que suscita la compatibilidad del proceso penal español con el art. 14.5 del PDCP se hubiera resuelto, tal vez, a través de una reserva a dicha disposición formulada en su momento.

19. Ciñéndonos a la sentencia del TEDH que condena a España y desemboca en el auto analizado, la misma destaca que el TS procedió a una nueva valoración de los elementos de la prueba practicada en la vista pública de la Audiencia Provincial sin haber tenido contacto directo con las partes ni haberles permitido exponer sus argumentos (apdo. 33). El Tribunal de Estrasburgo se remite, entre otras, a lo expuesto en la sentencia Serrano Contreras c. España (núm. 49183/08, del 20 de marzo de 2012) según la cual la conversión de la sentencia absolutoria en condenatoria exige la audiencia del absuelto. Alude a la especial rigidez de la sentencia absolutoria y concluye que en las circunstancias del caso concreto efectivamente los recurrentes han sido privados de su derecho a la defensa en el marco de un debate contradictorio.

20. El fallo, adoptado por unanimidad, consiste en declarar la violación del art. 6.1 del Convenio. Ahora bien, el TEDH no cuestiona el problema interno que la no doble instancia penal suscita en cuanto a la no conformidad con el Convenio, ni valora la naturaleza de las funciones ejercidas por los jueces españoles en sede de apelación, ni menciona la necesidad de una reforma legislativa al respecto. Se ciñe a los perjuicios ocasionados en el caso concreto.

21. Del análisis del presente auto se desprenden dos conclusiones generales. Comencemos por la que está directamente relacionada con el art. 6 del CEDH. A la vista de la sentencia del Tribunal de Estrasburgo, la decisión sobre el establecimiento de una segunda instancia de cognición plena permanece como una opción interna que requeriría una modificación procesal profunda en el ordenamiento español. Aparentemente, la medida sería más respetuosa con el principio de inmediación y con el derecho a la defensa, sin embargo, conllevaría problemas de fondo y de forma dado que rebajaría el peso de la primera instancia (la desvestiría) y obligaría a multiplicar el número de tribunales. Cargada de problemas estructurales y económicos, y dadas las circunstancias, la reforma puede esperar.

22. Finalmente, el auto refleja que la intención del TS es superar la dificultad derivada de la omisión legislativa para poder así acatar la sentencia del TEDH y responder a lo previsto en el art. 46 del CEDH. Ahora bien, el activismo judicial, aunque necesario en el caso, no es suficiente en el Derecho. Lo deseable sería que el collage de aportaciones jurisdiccionales al que se añade este auto se tradujera en un sistema reglado que remediara adecuadamente las anomalías expuestas, tarea que corresponde principalmente al legislador. Además, cabe esperar cierta celeridad, dado que se trata de una reforma siempre inminente, siempre necesaria y siempre pospuesta.

Joana ABRISKETA URIARTE Universidad de Deusto http://dx.doi.org/10.17103/redi.67.1.2015.3a.09 


\subsection{El contrato de trabajo por tiempo indefinido de apoyo a los emprendedores ante el Derecho internacional}

DERECHOS A LA IGUALDAD, LA TUTELA JUDICIAL EFECTIVA, LA LIBERTAD SINDICAL, AL TRABAJO Y A LA NEGOCIACIÓN COLECTIVA.-Organización Internacional del Trabajo.-Tratado internacional.-Contrato de trabajo de apoyo a emprendedores.-Periodo de prueba.

Sentencia del Tribunal Constitucional (Pleno) 119/2014, de 16 de julio. Ponente: Andrés Ollero Tassara. Voto particular: Fernando Valdés Dal-Ré, Adela Asua Batarrita, Luis Ignacio Ortega Álvarez.

Sentencia del Tribunal Superior de Justicia de Cataluña (Sala de lo Social, Sección 1. ${ }^{a}$ ), de 1 de julio de 2014 (ROJ: STSJ CAT 7887/2014). Ponente: José Quetcuti Miguel. Voto particular: Matilde Aragó Gassiot, Ascensión Solé Puig, Carlos Hugo Preciado Domenech, Daniel Bartomeus Plana, Lidia Castell Valldosera.

\section{ReferenciaCentrode DocumentaciónJudicial(Id.Cendoj) 08019340012014105208.}

1. El pasado 16 de julio de 2014, el Pleno del Tribunal Constitucional (TC) ha desestimado por amplia mayoría el recurso de inconstitucionalidad interpuesto por el Parlamento de Navarra en relación con la Ley 3/2012, de 6 de julio, relativa a las medidas urgentes para la reforma del mercado laboral (STC 199/2014, de 16 de julio). Esta sentencia ha conocido un Voto particular expresado por el Juez Fernando Valdés Dal-Ré respecto de algunas de las cuestiones de inconstitucionalidad planteadas en este asunto y con la parte dispositiva de este fallo, al que se adhirieron los Jueces Adela Asua Batarrita (vicepresidenta del TC) y Luis Ignacio Ortega Álvarez.

2. Por su parte, la Sala de lo Social, Sección 1. a , del TSJ de Cataluña se pronunció en este mismo semestre sobre un recurso de suplicación interpuesto frente a la sentencia del Juzgado Social núm. 33 de Barcelona, de 19 de noviembre de 2013, en la que se había declarado nulo el despido por fraude de ley y la vulneración de los derechos fundamentales previstos en los arts. 10, 14, 15 y 24 CE de una persona (madre soltera, con hijos menores a su cargo) que había recibido una comunicación escrita de despido disciplinario mientras se encontraba en situación de incapacidad temporal como consecuencia de un accidente de tráfico que había sufrido camino del trabajo (Sentencia 412/13 del Juzgado de lo Social de Barcelona, Sección 2. ${ }^{a}$ ).

3. Las dos sentencias objeto de atención en estos momentos giran en torno a varias disposiciones de la Ley 3/2012, de 6 de julio, de medidas urgentes para la reforma del mercado laboral (BOE núm. 162, de 7 de julio de 2012, pp. 49113-49191). Se trata de un acto normativo cuya adopción ha sido impulsada, en gran medida, por la situación de grave crisis atravesada por España a partir del año 2008. Crisis que ha puesto de manifiesto la existencia de numerosas debilidades del modelo laboral existente hasta entonces en este Estado. Debilidades que han propiciado la destrucción de empleo, la existencia de tasas muy elevadas de desempleo de larga duración, y también la existencia de un gran número de contratos de carácter temporal a costa de la creación de un número bastante bajo de contratos indefinidos. Ante esta situación, el Gobierno de España ha adoptado la mencionada ley que contiene numerosas medidas «incisivas y de aplicación inmediata» que buscan, entre otras, impulsar la creación de «un marco claro que contribuya a la gestión eficaz de las relaciones laborales y que facilite la creación de puestos de trabajo, así como la estabilidad en el empleo» tan necesaria en España (véanse los considerandos I y II de la Ley 3/2012). De entre las medidas 
adoptadas puede mencionarse a aquellas que tienen como objetivo el fomento de la contratación indefinida y el favorecer la creación del empleo, o aquellas otras que tratan de favorecer la flexibilidad interna en las empresas como alternativa a la destrucción de empleo [para un estudio detallado de las modificaciones introducidas en el mercado laboral español mediante la Ley 3/2012, de 6 de julio, véanse, entre otros: Castellano Burguillo, M. E. y Feria Basilio, I. R. (dirs.), Estudios en torno a la reforma laboral de 2012, Sevilla, Ed. Punto Rojo Libros, 2013; DE la Puebla Pinilla, A. M., «Flexibilidad interna y reforma laboral (Ley 3/2012)», Revista Jurídica Universidad Autónoma de Madrid, 2011, núm. 24, pp. 195-208].

4. En el recurso de inconstitucionalidad interpuesto por el Parlamento de Navarra se cuestionaba la conformidad con la CE de los arts. 4 y 14.1 y 3, y, por conexión, art. 14.2 y disposición adicional 5. ${ }^{a}$ de la citada Ley 3/2012. Siguiendo su doctrina sobre la posible extensión de los pronunciamientos de inconstitucionalidad y nulidad en virtud del art. 39.1 de la LOTC (STC 119/2014, de 16 de julio, FJ 2), finalmente el TC optó por analizar tres aspectos, polémicos sin duda, que le fueron planteados en este asunto, a saber: en primer lugar, el art. 4.3 relativo a la creación de un periodo de prueba de un año para el nuevo contrato de trabajo indefinido de apoyo a los emprendedores; en segundo lugar, el art. 14.1 que prevé la competencia de la Comisión Consultiva Nacional de Convenios Colectivos o de los órganos autonómicos equivalentes de decidir sobre la inaplicación de un convenio colectivo en aquellos casos de discrepancia entre la empresa y los trabajadores; y, en tercer lugar, el art. 14.3 relativo a la aplicación prioritaria de los convenios de empresa sobre los de ámbito superior (sectoriales) en determinadas materias.

5. Al hilo de la lectura de las alegaciones formuladas por las dos partes en este asunto puede afirmarse que el art. 4 de la Ley 3/2012 se ha encontrado en el centro de los argumentos empleados por las mismas. Siendo éste, además, como veremos seguidamente, la disposición de la Ley 3/2012 que mayor interés despierta desde el punto de vista del Derecho internacional. En relación con ello, cabe mencionar que el art. 4 de la Ley 3/2012 se incardina entre las disposiciones del Capítulo II de esta Ley relativas al fomento de la contratación indefinida y para favorecer la creación de empleo. En concreto, este art. 4 se refiere al contrato de trabajo por tiempo indefinido de apoyo a los emprendedores para empresas de menos de cincuenta trabajadores y tiene un carácter temporal y coyuntural pues, según la disposición transitoria novena apartado 2 de la Ley 3/2012, se aplicará hasta que la tasa de desempleo en España sea inferior al 15 por 100. Su epígrafe 3 prevé que «[e]l régimen jurídico del contrato y los derechos y obligaciones que de él se deriven se regirán, con carácter general, por lo dispuesto en el Texto Refundido de la Ley del Estatuto de los Trabajadores, aprobado por Real Decreto Legislativo 1/1995, de 24 de marzo, y en los convenios colectivos para los contratos por tiempo indefinido, con la única excepción de la duración del periodo de prueba a que se refiere el art. 14 del Estatuto de los Trabajadores, que será de un año en todo caso. No podrá establecerse un periodo de prueba cuando el trabajador haya ya desempeñado las mismas funciones con anterioridad en la empresa, bajo cualquier modalidad de contratación» (las cursivas son nuestras).

6. En relación con ello, cabe referirse al impacto mediático, político y jurídico que ha conocido el art. 4.3 de la Ley 3/2012, pues se ha prestado mucha atención a la cuestión de si el periodo de prueba de un año previsto en este artículo constituye, en realidad, un auténtico periodo de prueba o de si, por el contrario, ello implica una desnaturalización del periodo de prueba. En este sentido, en la actividad judicial de algunos de los órganos españoles se ha cuestionado tanto la constitucionalidad como 
el posible incumplimiento por parte de España de determinadas obligaciones convencionales asumidas en el ámbito internacional de algunas disposiciones de este acto normativo español.

7. En opinión del letrado recurrente, el art. 4.3 de la Ley 3/2012 vulnera el derecho al trabajo (art. 35.1 CE), la igualdad (art. 14 CE), la negociación colectiva (art. 37.1 $\mathrm{CE}$ ) y la tutela judicial efectiva (art. 24.1 CE). Así, por lo que se refiere a la posible violación del art. 35.1 CE, el Parlamento de Navarra estimaba que el periodo de prueba de un año no era razonable al apartarse de las exigencias del Convenio núm. 158 de la Organización Internacional del Trabajo (OIT), de la práctica laboral, y también del Derecho comparado en esta materia, tachándolo, también, de «injustificado» a la vista del mismo tratado internacional (STC 119/2014, de 16 de julio, FJ 3.A). Precisamente la atención prestada a la posible vulneración, en relación con la extensión del periodo de prueba en el contrato de trabajo de apoyo a emprendedores, del art. 35.1 CE y también de las obligaciones convencionales asumidas por España en el ámbito internacional en materia laboral, constituye el objeto central de los comentarios expuestos a continuación.

8. El Convenio núm. 158 de la OIT relativo a la terminación de la relación de trabajo fue ratificado por España mediante su publicación en el $B O E$ núm. 155, de 29 de junio de 1985 [para una presentación general de la OIT, véase DíEz DE VELASco, M. (Sobrino Heredia, J. M., coord.), Las Organizaciones internacionales, Madrid, Tecnos, 16. ${ }^{\mathrm{a}}$ ed., 2010, pp. 375-383]. Como es bien conocido, a partir de ese momento, con base en el art. 96.1 CE, este Convenio de la OIT pasó a formar parte integrante del Ordenamiento jurídico español. El art. 2.2 de esta norma convencional internacional autoriza a los Estados a excluir las garantías establecidas en la misma por lo que se refiere a «los trabajadores que efectúen un periodo de prueba o que no tengan el tiempo de servicios exigido», con el requisito de que «en uno u otro caso la duración se haya fijado de antemano y sea razonable». Por tanto, la OIT deja a los Estados la posibilidad de resolver la problemática de si la duración de los periodos de prueba es razonable o no, y el único límite del periodo de prueba es que se requiere que no sea «excesivamente largo». En relación con ello, cabe referirse a un informe emitido por el Comité de la OIT en un caso bastante parecido al de España, que se dio en Francia donde se había aprobado un tipo de contrato indefinido "para nuevas contrataciones» (Ordenanza núm. 2005-893); en esta ocasión, la OIT encontró que «no podría excluir la posibilidad de que estuviera justificado un periodo más dilatado para permitir a los empleadores medir la viabilidad económica y las perspectivas de desarrollo de su empresa, al tiempo que se posibilita a los trabajadores adquirir cualificaciones y experiencias» [STC 119/2014, de 16 de julio, FJ 3.A.e)].

9. En este contexto, y sobre las cuestiones planteadas en el recurso de inconstitucionalidad interpuesto por el Parlamento de Navarra, el TC consideró que era necesario determinar si en la situación actual de crisis en España la duración del periodo de prueba de un año en el contrato de apoyo a los emprendedores era razonable y proporcional. A pesar de que el Comité de la OIT encargado de emitir un informe en relación con la reclamación presentada respecto, entre otros, del art. 4.3 (Informe aprobado por el Consejo de Administración de la OIT en su 321. ${ }^{a}$ reunión de junio de 2014), siguiendo de hecho la doctrina de la OIT en la materia —que había estimado que no disponía de suficientes fundamentos "para considerar si la extensión de un año de la exclusión del campo de aplicación del Convenio pueda ser considerada como razonable, más aún cuando dicha extensión no ha sido el resultado de la concertación social y que la exclusión se ha introducido de manera general en dicha 
modalidad contractual» (apdo. 246)—, el TC consideró que «puede y debe emitir un pronunciamiento específico y fundamentado sobre la razonabilidad y proporcionalidad del impugnado art. 4.3 de la Ley 3/2012, a efectos de enjuiciar su constitucionalidad» [STC 119/2014, de 16 de julio, FJ 3.A.f)]. Finalmente, el TC concluyó que el art. 4.3 de la Ley 3/2012 no violaba el art. 35.1 CE ya que «en términos razonables y proporcionados pretende favorecer el acceso de desempleados a un puesto de trabajo estable, en el marco de una excepcional coyuntura de emergencia, caracterizada por elevadísimos niveles de desempleo, en ejecución del mandato que a los poderes públicos dirige el art. 40.1 CE» [STC 119/2014, de 16 de julio, FJ 3.A.f)].

10. Los tres magistrados del TC que emitieron un Voto particular en este asunto apuntaron la Sentencia de 1 de julio de 2008 de la Chambre Social de la Cour de Cassation francesa en la que el juez francés había declarado contraria al art. 4 del Convenio núm. 158 de la OIT la Ordenanza del año 2005 antes mencionada, que se aplicaba a las empresas de hasta 20 trabajadores, y en el que se preveía que durante los dos primeros años no se iba a aplicar más la norma general francesa que exigía la existencia de la causalidad del despido, pudiendo, por tanto, el empresario resolver el contrato ad nutum. Se consideró que un periodo de dos años era excesivo y, por tanto, no era razonable en el sentido de las disposiciones del Convenio núm. 158 de la OIT. Este enjuiciamiento francés ha sido interpretado por los tres magistrados del TC como un respaldo a la hora de afirmar que «resulta cuando menos paradójico que el legislador nacional pretenda promover el empleo incentivando las extinciones contractuales sin causa ni compensación económica, por reducida que sea» [STC 119/2014, de 16 de julio, Voto particular, punto 8.c. $\left.a^{\prime}\right)$ ]. De ahí que los tres magistrados del TC consideraran que el TC tenía que haber declarado la inconstitucionalidad y nulidad del art. 4.3 de la Ley 3/2012 por haber sido violado el principio de causalidad de las extinciones contractuales debidas a la voluntad del empresario, en su condición de contenido esencial del derecho al trabajo recogido por el art. 35.1 CE (STC 119/2014, de 16 de julio, Voto particular, punto 9).

11. Por lo que se refiere al posible incumplimiento por parte de España de determinadas obligaciones convencionales internacionales asumidas en esta materia, hay que mencionar que el periodo de prueba de un año en el caso del nuevo contrato de trabajo de apoyo a los emprendedores ha sido considerado por el Juzgado de lo Social de Barcelona, Sección 2. ${ }^{a}$, en su Sentencia núm. 412/13, de 19 de noviembre, contrario al art. 4.4 de la Carta Social Europea (CSE) de 1961 (la versión revisada de la misma en el año 1996 no ha sido ratificada todavía por España hasta la fecha) pues en él no se establece ningún plazo de preaviso y tampoco una indemnización a su finalización dentro de dicho plazo (FJ 5) (al respecto, véase INDA ERREA, M., «El periodo de prueba de un año del contrato de apoyo a emprendedores vulnera la Carta Social Europea», Revista Aranzadi Doctrinal, 2014, núm. 9). El art. 4.4 de la CSE prevé el compromiso de las partes en un contrato de trabajo de «reconocer el derecho de todos los trabajadores a un plazo razonable de preaviso en caso de terminación del empleo». Por tanto, el periodo de prueba de un año no podría ser considerado razonable. Además, en el Voto particular expresado en la STC 119/2014, de 16 de julio, se mencionaba la resolución del Comité Europeo de Derechos Sociales publicada en el año 2013 en relación con la queja formulada por distintos sindicatos griegos en lo referido a la introducción de un periodo de prueba de un año de duración en unos nuevos contratos de trabajo creados en Grecia en el año 2010. En dicha ocasión, el Comité Europeo de Derechos Sociales consideró (por unanimidad) que el mencionado periodo de prueba era contrario al art. 4.4 de la CSE no solamente porque podría ser considerado demasiado amplio y que su duración fuese demasiado prolongada en 
el tiempo, determinando que las garantías referidas a la notificación y el pago de una indemnización por despido fuesen ineficaces, sino también porque en la legislación griega no se preveía ningún periodo de notificación y tampoco el pago de una indemnización en caso de la extinción del contrato de trabajo durante el periodo de prueba de un año [STC 119/2014, de 16 de julio, Voto particular, punto 3.b)].

12. Pero, tal y como se ha apuntado por una parte de la doctrina laboralista española (al respecto, véase Gómez ABELLEIRA, F. J., «El contrato de apoyo a emprendedores ante el Derecho internacional. Comentario a la Sentencia del Juzgado de lo Social núm. 2 de Barcelona de 19 de noviembre de 2013», Información Laboral, 2014, núm. 1, p. 3), el art. 4.4 de la CSE no contiene ninguna disposición referida a la extinción del contrato y tampoco sobre el periodo de prueba. Esto es, el periodo de prueba de un año de duración del contrato de apoyo a los emprendedores realmente no es contrario a la CSE, y lo que parece ser contrario a este tratado internacional es el hecho de que una relación laboral en el Ordenamiento jurídico español se dé por terminada sin preaviso alguno. $\mathrm{O}$, dicho de otra forma, hay que distinguir entre la extensión del periodo de prueba, por un lado, y el preaviso exigible para la correcta terminación de un contrato laboral, por otro lado. En numerosas ocasiones España ha sido avisada por el Comité Europeo de Derechos Sociales que su legislación relativa a la extinción de los contratos temporales violaba el art. 4.4 de la CSE. Pero, respecto de la duración del periodo de prueba, España no vulnera las mencionadas disposiciones de este tratado internacional (para un detallado estudio de estas cuestiones, véase Gómez Abelleira, F. J., op. cit., pp. 4-6).

13. Esta carencia del Ordenamiento jurídico español relativa al preaviso en un contrato laboral ha tenido consecuencias negativas directas sobre las empresas españolas que han aplicado de buena fe la legislación laboralista vigente en España, pero que han visto cómo sus actuaciones han sido penalizadas, en un primer momento, por los órganos judiciales españoles. Ello ha quedado patente en la mencionada Sentencia del Juzgado de lo Social de Barcelona núm. 2, de 19 de noviembre de 2013, y reconocido implícitamente por la sentencia del TSJ de Cataluña, Sala de lo Social, Sección 1. ${ }^{a}$, de 1 de julio de 2014, en la que se estima el recurso de suplicación interpuesto contra la sentencia antes indicada. Como es bien conocido, los órganos judiciales españoles se encargan de aplicar el Derecho y no de crear el Derecho. Esta situación existente en el Ordenamiento jurídico español podría ser cambiada solamente a través de la actuación del legislador español que bien podría adaptar su legislación en este ámbito a las exigencias de la CSE que, de hecho, España ha asumido ya en el momento de la ratificación de este tratado internacional, o bien podría no aceptar más el art. 4.4 de la CSE. En relación con este segundo supuesto, España podría hacer una declaración interpretativa del art. 4.4 de la CSE según el art. 2.t) de la Ley 25/2014, de 27 de noviembre, de Tratados y otros Acuerdos Internacionales (BOE núm. 288, de 28 de noviembre de 2014, p. 96841), para precisar o aclarar el sentido o el alcance que atribuye a esta disposición de un texto jurídico internacional. Y a partir de ese momento, según el art. 35.3 de la nueva Ley 25/2014, las disposiciones de la CSE se interpretarían «conforme al sentido conferido en ellas».

14. En definitiva, los órganos judiciales españoles han avalado el periodo de prueba de un año establecido en la Ley 3/2012, de 6 de julio, relativa a las medidas urgentes para la reforma del mercado laboral. 